\title{
Water Quality Assessment of the Sacramento River Basin, California-Environmental Setting and Study Design
}

By Joseph L. Domagalski, Donna L. Knifong, Dorene E. MacCoy, Peter D. Dileanis, Barbara J. Dawson, and Michael S. Majewski

U.S. GEOLOGICAL SURVEY

Water-Resources Investigations Report 97-4254

National Water-Quality Assessment Program

Ð
๖

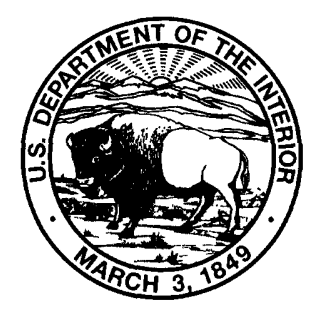




\section{U.S. DEPARTMENT OF THE INTERIOR BRUCE BABBITT, Secretary}

\section{U.S. GEOLOGICAL SURVEY}

Thomas J. Casadevall, Acting Director

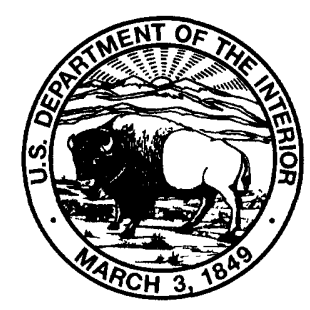

The use of firm, trade, and brand names in this report is for identification purposes only and does not constitute endorsement by the U.S. Geological Survey.

For additional information write to:

District Chief

U.S. Geological Survey

Water Resources Division

Placer Hall

$6000 \mathrm{~J}$ Street

Sacramento, CA 95819-6129
Copies of this report can be purchased from:

U.S. Geological Survey

Branch of Information Services

Box 25286

Denver, CO 80225-0286 


\section{FOREWORD}

The mission of the U.S. Geological Survey (USGS) is to assess the quantity and quality of the earth resources of the Nation and to provide information that will assist resource managers and policymakers at Federal, State, and local levels in making sound decisions. Assessment of water-quality conditions and trends is an important part of this overall mission.

One of the greatest challenges faced by waterresources scientists is acquiring reliable information that will guide the use and protection of the Nation's water resources. That challenge is being addressed by Federal, State, interstate, and local water-resource agencies and by many academic institutions. These organizations are collecting water-quality data for a host of purposes that include: compliance with permits and water-supply standards; development of remediation plans for specific contamination problems; operational decisions on industrial, wastewater, or watersupply facilities; and research on factors that affect water quality. An additional need for water-quality information is to provide a basis on which regionaland national-level policy decisions can be based. Wise decisions must be based on sound information. As a society we need to know whether certain types of water-quality problems are isolated or ubiquitous, whether there are significant differences in conditions among regions, whether the conditions are changing over time, and why these conditions change from place to place and over time. The information can be used to help determine the efficacy of existing waterquality policies and to help analysts determine the need for and likely consequences of new policies.

To address these needs, the U.S. Congress appropriated funds in 1986 for the USGS to begin a pilot program in seven project areas to develop and refine the National Water-Quality Assessment (NAWQA) Program. In 1991, the USGS began full implementation of the program. The NAWQA Program builds upon an existing base of water-quality studies of the USGS, as well as those of other Federal, State, and local agencies. The objectives of the NAWQA Program are to:

- Describe current water-quality conditions for a large part of the Nation's freshwater streams, rivers, and aquifers.

- Describe how water quality is changing over time.
- Improve understanding of the primary natural and human factors that affect water-quality conditions.

This information will help support the development and evaluation of management, regulatory, and monitoring decisions by other Federal, State, and local agencies to protect, use, and enhance water resources.

The goals of the NAWQA Program are being achieved through ongoing and proposed investigations of 60 of the Nation's most important river basins and aquifer systems, which are referred to as study units. These study units are distributed throughout the Nation and cover a diversity of hydrogeologic settings. More than two-thirds of the Nation's freshwater use occurs within the 60 study units and more than twothirds of the people served by public water-supply systems live within their boundaries.

National synthesis of data analysis, based on aggregation of comparable information obtained from the study units, is a major component of the program. This effort focuses on selected water-quality topics using nationally consistent information. Comparative studies will explain differences and similarities in observed water-quality conditions among study areas and will identify changes and trends and their causes. The first topics addressed by the national synthesis are pesticides, nutrients, volatile organic compounds, and aquatic biology. Discussions on these and other waterquality topics will be published in periodic summaries of the quality of the Nation's ground and surface water as the information becomes available.

This report is an element of the comprehensive body of information developed as part of the NAWQA Program. The program depends heavily on the advice, cooperation, and information from many Federal, State, interstate, Tribal, and local agencies and the public. The assistance and suggestions of all are greatly appreciated.

$$
\begin{array}{r}
\text { Covent } n \text {. Mtrach } \\
\text { Robert M. Hirsch } \\
\text { Chief Hydrologist }
\end{array}
$$




$$
\text { | }
$$




\section{CONTENTS}

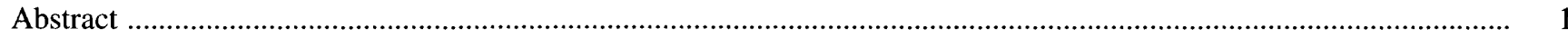

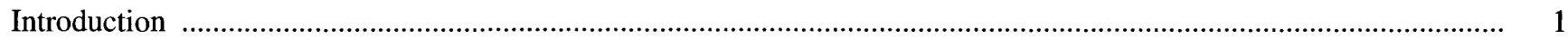

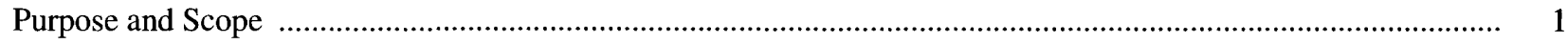

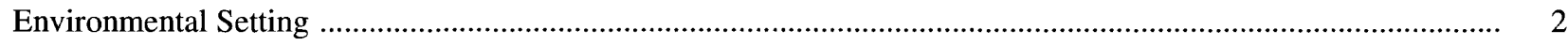

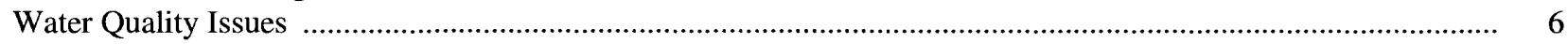

Occurrence and Distribution Assessment Activities ……………………………………………………... 13

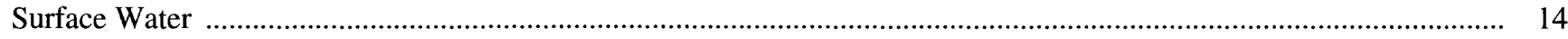

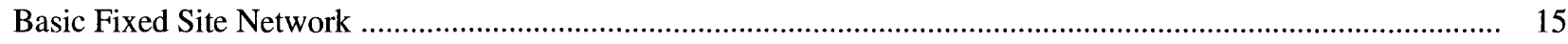

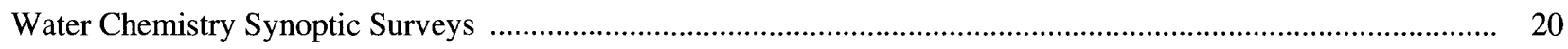

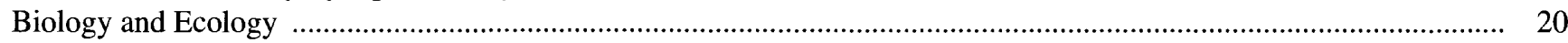

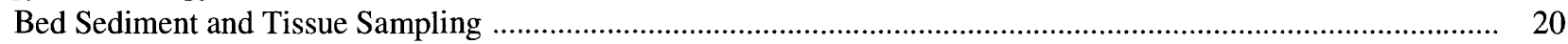

Ecological Issues Within the Sacramento River Basin ....…………………………………………………... 23

Ecological Surveys of the Sacramento River Basin ……………………………………………………...... 23

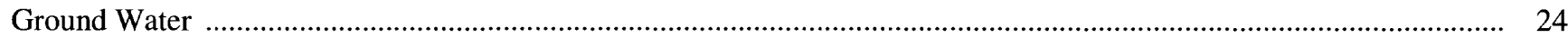

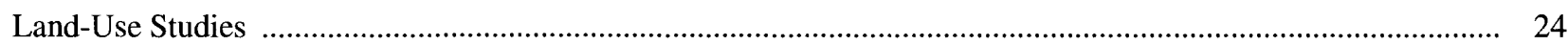

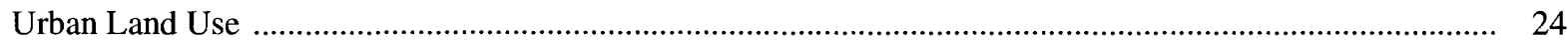

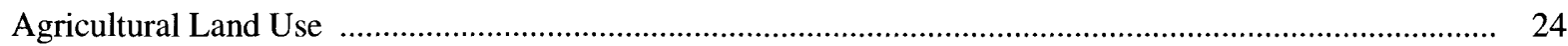

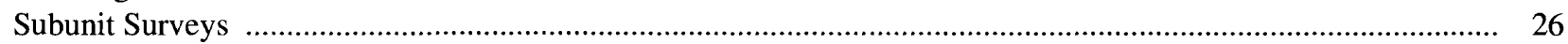

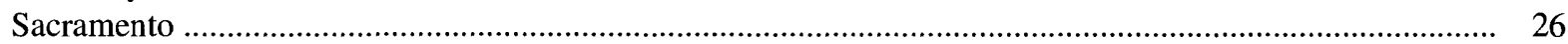

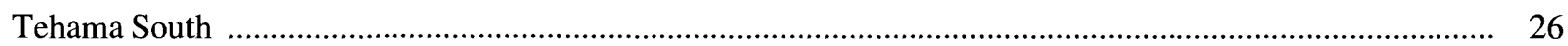

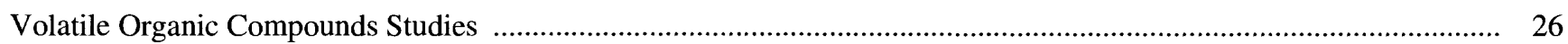

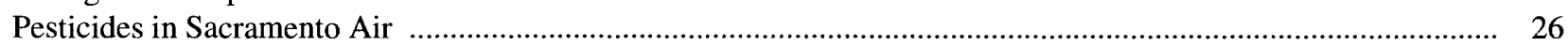

Volatile Organic Compounds in Surface Water ............................................................................................... 29

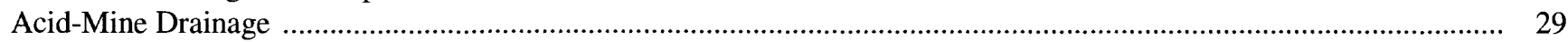

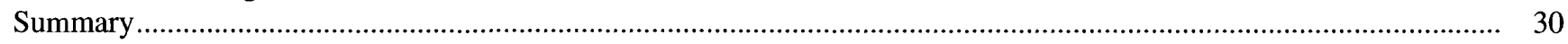

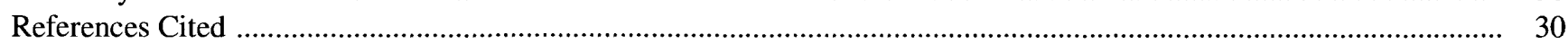

\section{FIGURES}

1.-5. Maps showing:

1. Location of Sacramento River Basin, California, study unit .............................................................

2. Physiographic provinces of the Sacramento River Basin, California ................................................... 4

3. Ecological regions of the Sacramento River Basin, California ............................................................ 5

4. Geologic regions of the Sacramento Valley, California ......................................................................... 7

5. Land use of the Sacramento River Basin, California ......................................................................... 9

6. Physiographic and land-use classification for the Sacramento River Basin, California ................................. 10

7. Soil infiltration regions of the Sacramento River Basin, California ......................................................... 11

8. Water allocated for various uses in the Sacramento Valley, California, in 1990 ........................................... 12

9. Daily mean discharge of the Sacramento River at Freeport, California, June 1, 1992,

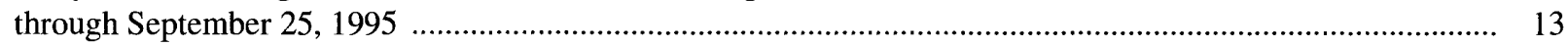

10. Timeline of National Water-Quality Assessment Program activities ...................................................... 14

11. National Water-Quality Assessment Program components of the Occurrence and Distribution Assessment ...... 14

12. Graph showing plot of sodium as a function of discharge for the Sacramento River at Freeport, California ....... 16

13.-18. Maps showing:

13. Basic and intensive fixed sites for the Sacramento River Basin, California, National Water-Quality Assessment Program

14. Basic fixed site network and drainage basins for the Sacramento River Basin, California, National Water-Quality Assessment Program

15. Bed sediment and tissue (from fish and aquatic animals) sampling sites for the Sacramento River Basin, California, National Water-Quality Assessment Program 
16. Candidate settings for ground water land-use studies for the Sacramento River Basin, California, National Water-Quality Assessment Program

17. Major aquifer subunits and ground water use for 1989 in the Sacramento River Basin, California

18. Air and surface water sampling sites for volatile organic compounds, Sacramento River Basin, California National Water-Quality Assessment Program

\section{TABLES}

1. Water-balance plan for the Sacramento River Basin for 1990 and 2020

2. Sacramento River Basin National Water-Quality Assessment Program: Basic and intensive fixed sites

3. Bed sediment and tissue (from fish and aquatic animals) sampling sites of the Sacramento River Basin

\section{CONVERSION FACTORS, VERTICAL DATUM, AND ABBREVIATIONS AND ACRONYMS}

\section{Conversion Factors}

\begin{tabular}{rcl}
\hline Multiply & By & To obtain \\
\hline acre-foot $(\mathrm{acre} / \mathrm{ft})$ & 1,233 & cubic meter $\left(\mathrm{m}^{3}\right)$ \\
cubic foot per second $\left(\mathrm{ft}^{3} / \mathrm{s}\right)$ & 0.02832 & cubic meter per second $\left(\mathrm{m}^{3} / \mathrm{s}\right)$ \\
foot $(\mathrm{ft})$ & 0.3048 & meter $(\mathrm{m})$ \\
gallon $(\mathrm{gal})$ & 3.785 & liter $(\mathrm{L})$ \\
gallon per minute $(\mathrm{gal} / \mathrm{min})$ & 3.785 & liter per minute $(\mathrm{L} / \mathrm{min})$ \\
inch (in.) & 2.54 & centimeter $(\mathrm{cm})$ \\
inch per year (in./yr) & 25.4 & millimeter per year $(\mathrm{mm} / \mathrm{yr})$ \\
mile $(\mathrm{mi})$ & 1.609 & kilometer $(\mathrm{km})$ \\
square mile $\left(\mathrm{m}^{2}\right)$ & 2.590 & square kilometer $\left(\mathrm{km}^{2}\right)$ \\
\hline
\end{tabular}

Temperature is given in degrees Celsius $\left({ }^{\circ} \mathrm{C}\right)$, which can be converted to degrees Fahrenheit $\left({ }^{\circ} \mathrm{F}\right)$ by the following equation:

$$
{ }^{\circ} \mathrm{F}=1.8\left({ }^{\circ} \mathrm{C}\right)+32 \text {. }
$$

\section{Vertical Datum}

Sea level: In this paper, "sea level" refers to the National Geodetic Vertical Datum of 1929-a geodetic datum derived from a general adjustment of the first-order level nets of the United States and Canada, formerly called Sea Level Datum of 1929.

\section{Abbreviations and Acronyms}

CRWQCB, California Regional Water Quality Control Board

GFF, glass fiber filter

$\mathrm{m} / \mathrm{s}$, meter per second

$\mu \mathrm{g} / \mathrm{L}$, microgram per liter

$\mathrm{mg} / \mathrm{L}$, milligram per liter

NAWQA, National Water-Quality Assessment

NWQL, National Water-Quality Laboratory

PUF, polyurethane foam

RASA, Regional Aquifer Systems Analysis

USGS, U.S. Geological Survey

VOC, volatile organic compound 


\title{
Water Quality Assessment of the Sacramento River Basin, California- Environmental Setting and Study Design
}

\author{
by Joseph L. Domagalski, Donna L. Knifong, Dorene E. MacCoy, Peter D. Dileanis, \\ Barbara J. Dawson, and Michael S. Majewski
}

\section{Abstract}

This report describes the environmental setting and investigative activities of the Sacramento River Basin study unit of the National Water-Quality Assessment Program. The Sacramento River Basin is one of 60 study units located throughout the United States that has been scheduled for study as part of the National WaterQuality Assessment Program. The Sacramento River Basin is the most important source of freshwater in California. Water quality studies in the Sacramento River Basin study unit focus on the Sacramento Valley because it is here that the principal uses of water and potential impacts on water quality occur. Investigative activities include a network of surface water sites, where water chemistry and aquatic biological sampling are done, and a variety of ground water studies. In addition, investigations of the cycling and distribution of volatile organic compounds in the urban environment and the distribution of total and methyl mercury in the Sacramento River and tributaries will be completed.

\section{INTRODUCTION}

In 1991, the U.S. Geological Survey (USGS) began full-scale implementation of the National Water-Quality Assessment (NAWQA) Program. The objectives of NAWQA are to describe (1) current water quality conditions for a large part of the nation's freshwater streams, rivers, and aquifers; (2) trends in water quality over time; and (3) ways to improve understanding of the primary natural and human factors that affect water quality conditions. This information is useful for planning management actions and examining their likely consequences. Investigations of water quality in 60 major hydrologic basins and aquifer systems, referred to as NAWQA study units, are being done on a staggered time scale. The NAWQA Program initially focused on a set of 20 study units. The Sacramento River Basin was selected as one of the second 20 study units to begin data collection and analysis in 1994. The study unit's sampling design includes surface water, ground water, biological, and atmospheric investigative activities. Data collection efforts in the Sacramento River Basin began in 1995 and will be completed in 1998 .

\section{Purpose and Scope}

The purpose of this report is to describe the environmental setting of the Sacramento River Basin study unit and the selection of sampling sites for surface water, biological, ground water, and atmospheric studies for the NAWQA Program. The selection of sampling sites is based on the environmental setting of the basin and, for surface water sites, the possibility to integrate chemical and biological studies. The process of selecting sampling sites is the same for all NAWQA study units. The scope of this report includes a detailed description of the environmental setting of the basin, the rationale for the selection of sites, and 
the design of specific investigative activities. This report provides baseline and historical information for additional reports that will address specific water quality issues and processes controlling and affecting water quality in the study area, and for reports that integrate the results of the investigations across the nation (national-synthesis component of the NAWQA Program).

\section{Environmental Setting}

The Sacramento River Basin study unit (fig. 1) consists of the following physiographic provinces: Sacramento Valley, Coast Ranges, Klamath Mountains, Cascade Mountains, Sierra Nevada, Modoc Plateau, and the Sacramento-San Joaquin Delta (fig. 2). Ecological regions (ecoregions) are shown in figure 3. Physiographic provinces are defined as regions that have relatively similar geological history and structure and climatic patterns. Ecoregions are defined on the basis of homogeneity of characteristics, such as climate, soils or geology, vegetation, and physiography (Omernik, 1986).

Stream reaches or ground water may be compared and contrasted within the various physiographic provinces or ecoregions as part of NAWQA planning and study design elements.

The ecoregions shown in figure 3 are different from the physiographic regions, shown in figure 2, because more emphasis is given to defining regions of similar characteristics important to biological communities. Physiographic regions, on the other hand, are defined more on the basis of geology. The Modoc Plateau, a volcanic tableland formed from 5 to 25 million years ago, is coincident with the age of the Cascade Mountains (Schoenherr, 1992). The elevation averages between 4,000 and 5,000 ft above sea level (Schoenherr, 1992). The Pit River (see fig. 1), the largest river draining this region of the basin, once drained directly into the Sacramento River, but now drains into Shasta Lake. The Modoc Plateau has cold, snowy winters and only moderate rainfall the rest of the year. The average annual precipitation is $12 \mathrm{in}$.

The Cascade Mountains in California are the southernmost extension of a range extending from southern British Columbia, Canada. The rocks of the Cascade Mountains are predominantly volcanic in origin (Norris and Webb, 1990). Precipitation over the western part of the Cascade Mountains in California averages about 80 in./yr (Schoenherr, 1992).
Vegetation in the Cascade Mountains generally is alpine or subalpine forest.

The Sierra Nevada is the most prominent topographic feature in California. The central and southern Sierra Nevada is composed chiefly of granitic plutonic rock; volcanic and sedimentary rocks are more common in the northern Sierra Nevada. The bulk of the plutonic rocks of the Sierra Nevada are late Jurassic to late Cretaceous in age (Norris and Webb, 1990). Total precipitation is up to $80 \mathrm{in} . / \mathrm{yr}$, and corresponding runoff from the Sierra Nevada is collected in reservoirs, which provide irrigation water for agriculture and drinking water for downstream communities. Dense coniferous forests are found throughout the western slope of the Sierra Nevada (Schoenherr, 1992).

The Coast Ranges form a series of northwest-tosoutheast trending ridges and valleys associated with faulting and folding (Schoenherr, 1992). The rocks of the Coast Ranges are extremely diverse, but consist mainly of marine sediment. The vegetation of the Coast Ranges bordering the western Sacramento Valley includes communities mainly of oak and pine woodlands, as described in Schoenherr (1992) as "well-spaced trees and a grassy understory." Rainfall is variable within the Coast Ranges, but totals can reach up to $60 \mathrm{in./yr} \mathrm{(Jacobs} \mathrm{and} \mathrm{others,} \mathrm{1993).}$

The Klamath Mountains form a complex series of rocks dating from the early Paleozoic to the present and include accreted terrains, oceanic crust, and subduction zone complexes (Norris and Webb, 1990). Precipitation totals are among the highest in northern California and approach $140 \mathrm{in} . / \mathrm{yr}$ in some locations. Most of the major rivers of the Klamath Mountains drain to the Pacific Ocean, but some drainage goes to the Sacramento River Basin. Vegetation in the Klamath Mountains is similar to the Coast Ranges with extensive Douglas fir forests.

Of the seven physiographic provinces shown in figure 2, the Sacramento Valley has been given the most attention because it is in this province that the greatest amount of water use and potential impacts on water use occur. The other physiographic provinces are relatively sparsely populated. Their land uses are less intense, although the potential to impact downstream water quality does exist, particularly in the Coast Ranges, the Sierra Nevada, and the Klamath Mountains. The Coast Ranges and the Sierra Nevada are potential sources of mercury and other trace elements to the adjacent lowlands; the Klamath 


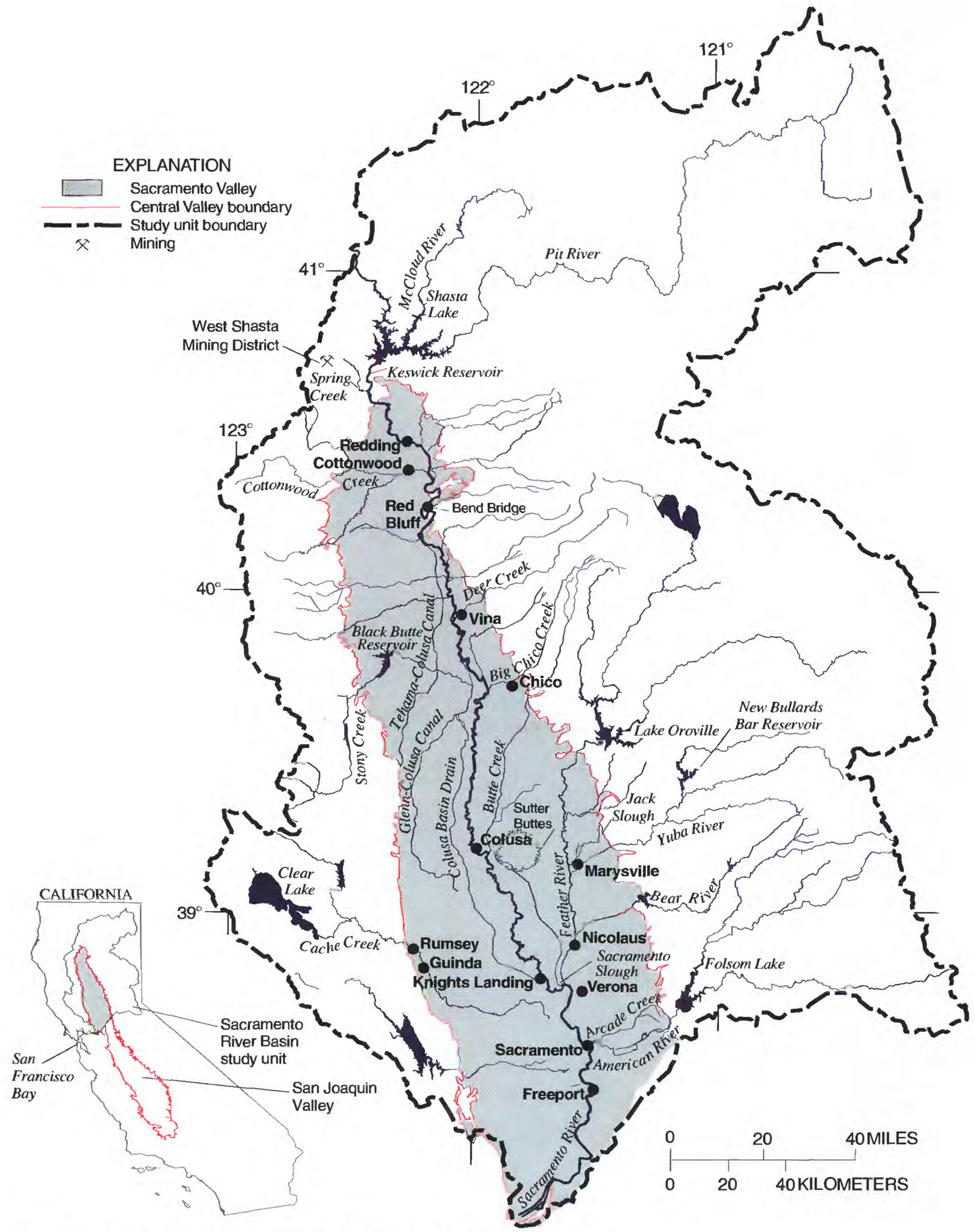

Figure 1. Location of Sacramento River Basin, California, study unit. 


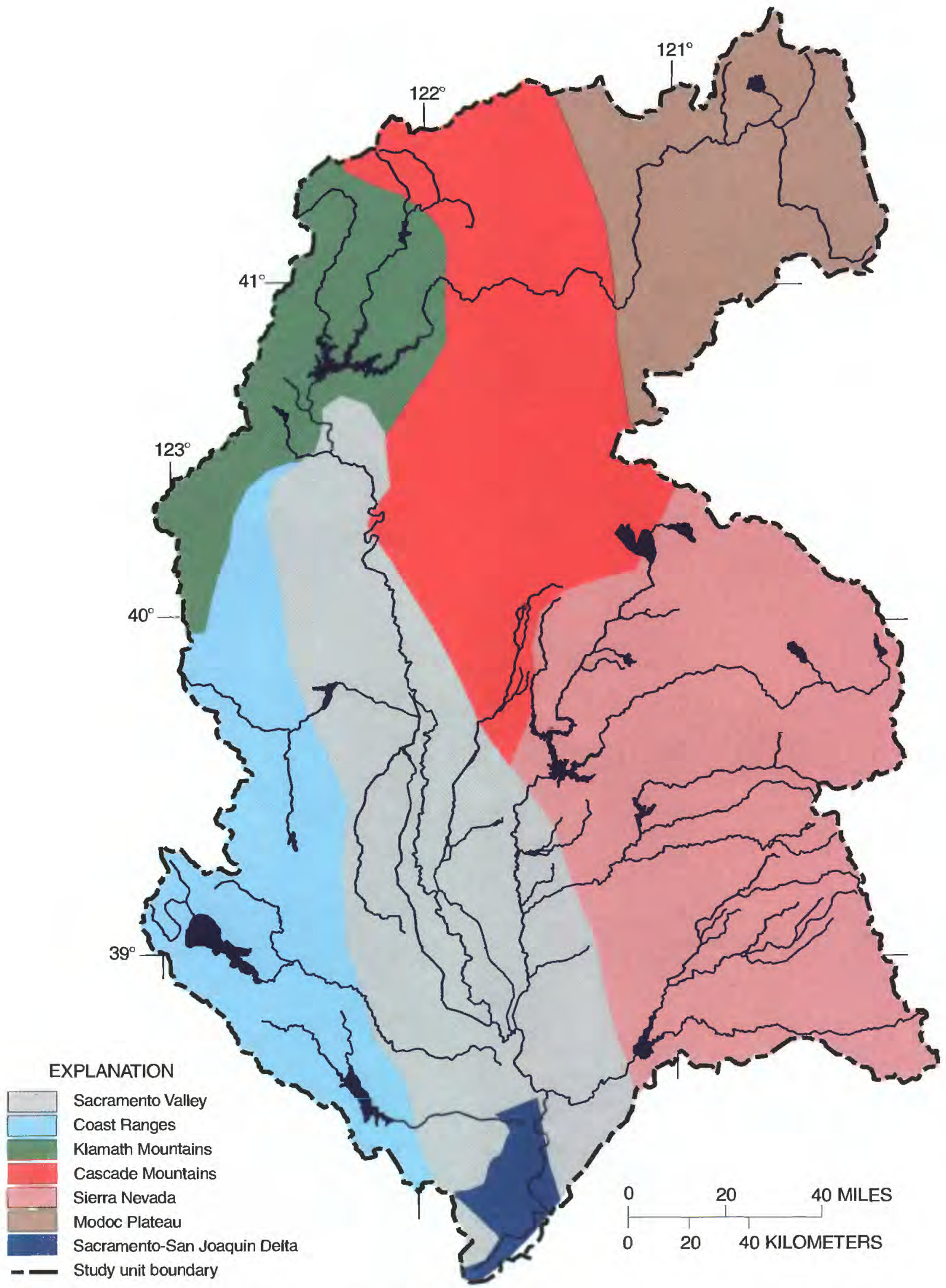

Figure 2. Physiographic provinces of the Sacramento River Basin, California. 


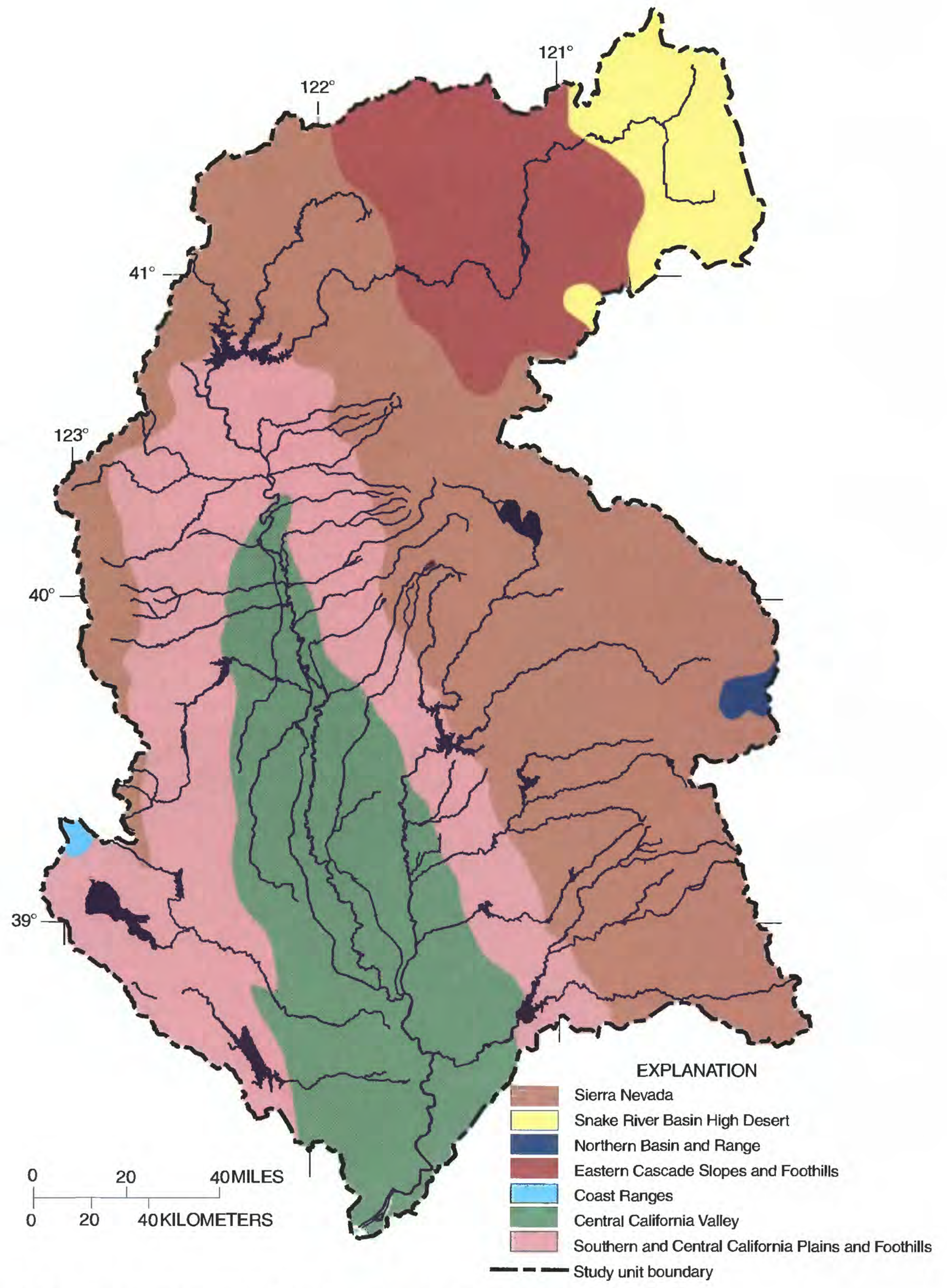

Figure 3. Ecological regions (ecoregions) of the Sacramento River Basin, California. 
Mountains are a major source of trace elements to the upper Sacramento River (below Shasta Lake in fig. 1).

The geology of the Sacramento Valley has been described by Page (1986). To summarize Page's description, the Sacramento Valley is part of the northwestward-trending asymmetric-structural trough of the Central Valley (fig. 1) that has been filled with as much as $10 \mathrm{mi}$ thickness of sediment. The ages of the sedimentary rocks and deposits in the Sacramento Valley range from Jurassic to Holocene and include marine and continental rocks and deposits. A geologic map of the Sacramento Valley is shown in figure 4. Mean annual precipitation within the Sacramento Valley ranges from 14 to $25 \mathrm{in}$. (Page, 1986).

A land-use map and a diagrammatic representation of physiographic and land-use classifications are shown in figures 5 and 6 , respectively. The land uses of the Sacramento Valley are dominated by agriculture. Orchards - principally walnut, almond, prune, and peach - are located along river channels to take advantage of well-drained soils. Rice is one of the principal crops because of the relatively impermeable soils of the valley and the availability of irrigation water from the Sacramento River. Most of the soils of the Sacramento Valley are fine-grained (fig. 7) with low permeability. The largest city in the study unit, with a population of over one million in the metropolitan area, is Sacramento. Sacramento is located near the southernmost part of the study unit, at the confluence of the Sacramento and American Rivers (fig. 1). The total population of the study unit is 2,208,900, according to the 1990 census (U.S. Department of Commerce, 1992).

The average annual precipitation for the Sacramento River Basin is 36 in., most of which occurs as rain or snow during the months of November through March. The average annual runoff from the basin is 22,389,700 acre-ft (California Department of Water Resources, 1993). All the major rivers of the basin-Sacramento, Feather, American, and Yubaare impounded just above the margin of the Sacramento Valley (fig. 1). The reservoirs are managed to collect snowmelt and to provide flood protection. The upper Sacramento River, the McCloud River, and the Pit River supply water to Shasta Lake, which has a capacity of 4,552,000 acre-ft. Lake Oroville, on the Feather River, has a capacity of 3,537,600 acre-ft. Folsom Lake, on the American River, has a capacity of 974,500 acre-ft. New Bullards Bar Reservoir, on the Yuba River, has a capacity of
966,100 acre- $\mathrm{ft}$. The amount of snowmelt runoff to these reservoirs on an annual or multiannual cycle dominates the discussions of water allocation for various water users throughout the basin and for export to other locations in California. Water is released from the reservoirs during spring and summer to provide irrigation water to agricultural communities in the Sacramento and San Joaquin Valleys. This water also provides drinking water to these Central Valley residents and to residents of southern California and is used to lower the salinity of the Sacramento-San Joaquin Delta by dilution. Water entering the reservoirs is of high quality, so the focus of this study will be on downstream impacts. The reservoirs have blocked the routes of migratory fish, such as salmon and steelhead trout; therefore, the remaining populations and the impacts on these populations are in the reaches of river below the reservoirs.

A water-balance plan (table 1) for the Sacramento River Basin for 1990 and 2020 has been prepared by the California Department of Water Resources (1993). The plan, which changes in response to changes in precipitation, snowmelt runoff to the major reservoirs, reservoir capacity, and demand, is used to allocate water for urban, agricultural, environmental, and other uses. The relative amounts of water allocated in 1990 are shown in figure 8. Flows of the Sacramento, Feather, Yuba, and American rivers, which increase during the winter and spring months, are managed throughout the year by reservoir releases. A plot of daily mean discharge on the Sacramento River at Freeport, located near the mouth of the basin, is shown in figure 9 for June 1992 though September 1995. Although this plot illustrates the vast differences in flow at Freeport during wet and dry years, during the 2 wet years (1993 and 1995) an equivalent amount of flow was diverted though a flood control channel into the San Francisco Bay estuary and, therefore, the discharge at Freeport did not represent the total amount of water leaving the basin.

\section{Water Quality Issues}

A liaison committee consisting of federal, state, and local water management and water quality agencies has been formed for the purpose of planning and coordinating water quality studies in the Sacramento River Basin. The major water quality issues currently affecting the Sacramento River Basin, as defined by discussions with members of the liaison 


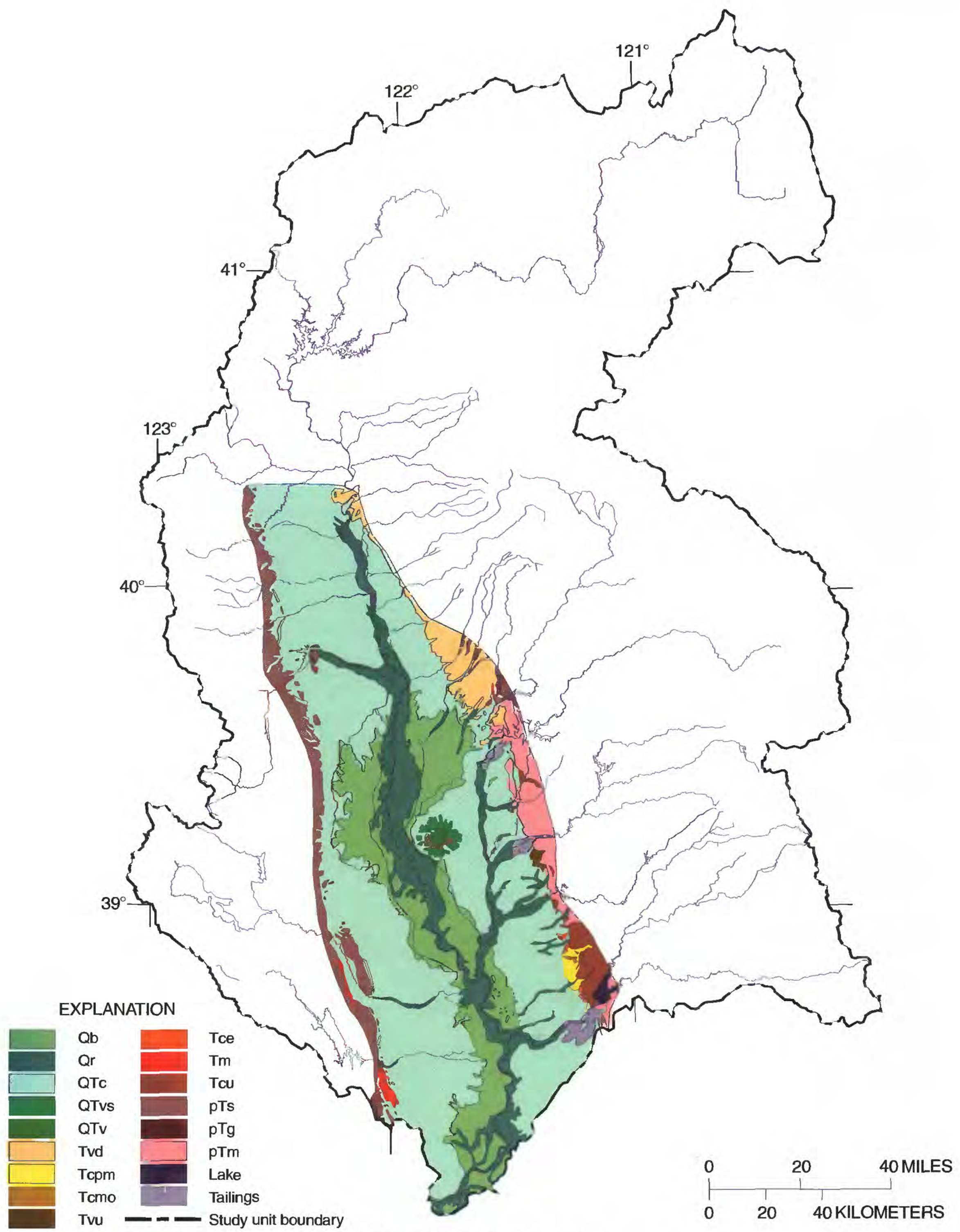

Figure 4. Geologic regions of the Sacramento Valley, California. Modified from Page (1986). 
Flood-basin deposits (Holocene)-Clay, silt, and some sand deposited during flood stages of major streams; in delta area, includes mud, muck, loam, and sand. In some places may include part of the Modesto Formation (Pleistocene).

River deposits (Holocene) - Gravel, sand, silt, and minor amounts of clay deposited along channels, flood plains, and natural levees of major streams. In some places may include part of the Modesto Formation (Pleistocene).

Continental rocks and deposits (Pliocene to Holocene)-Heterogeneous mix of generally poorly sorted clay, silt, sand, and gravel; some beds of claystone, siltstone, sandstone, and conglomerate. Includes some informal units: younger alluvium (Holocene), older alluvium (Pleistocene and possibly Holocene), and fanglomerate (Pleistocene); four formations of Pleistocene age: Red Bluff, Modesto, Riverbank, and Turlock Lake; the Tehama Formation (Pliocene and Pleistocene) on western side of valley; and the Laguna Formation (Pliocene) on eastern side. Difficult to determine subsurface contacts of formations and informal units.

Volcanic rocks and deposits at Sutter Buttes (Pliocene and Pleistocene)-Tuff and tuff breccia.

Volcanic rocks (Pliocene and Pleistocene)--Andesitic and rhyolitic porphyry and tuff at core of Sutter Buttes.

Volcanic rocks and deposits (Miocene and Pliocene)-Andesite; obsidian; pumice; tuff; volcanic breccia, gravel, and sand; volcanic mudflows; some basalt. Includes Tuscan Formation (Pliocene) in the northeastern part of valley, Nomlaki Tuff Member (Pliocene) of the Tehama Formation in western part, Lawlor Tuff (Pliocene) and Sonoma Volcanics (Miocene and Pliocene) in southwestem part, and Lovejoy Basalt (Miocene) near Oroville.

Continental rocks and deposits (Miocene and Pllocene) - Gravel, sand, silt, clay, breccia, conglomerate, sandstone, and andesitic material. Principally Mehrten Formation on eastern side of valley.

Continental rocks and deposits (Oligocene and Miocene)—Gravel, sand, silt, clay, siltstone, numerous tuffaceous beds, and rhyolitic material. Principally Valley Springs Formation on eastern side of valley.

Volcanlc rocks (Uncertain age)-Andesite and basalt. Basalt at Orland Buttes may include Lovejoy Basalt (Miocene and andesitic material east of Marysville includes Reeds Creek Andesite of Clark and Anderson [1938] of late Eocene or Oligocene age).

ContInental rocks and deposits (Eocene)-Sand, clay, sandy to gravelly clay, sandstone; contain anauxite. Principally Ione Formation on eastern side of valley, may include some of Valley Springs Formation (Oligocene and Miocene).

Marine rocks and deposits (Paleocene and Eocene)-Sand, clay, sandy to gravelly clay, and sandstone. Includes Nortonville Shale Member of Kreyenhagen Formation (Eocene), Domegine Formation (Eocene), Martinez Formation (Paleocene), and some Paleocene rocks and deposits on western side of valley.

Continental rocks and deposits (Uncertaln age)_Auriferous and nonauriferous gravel on eastern side of valley, volcanic claystone, mudstone, and lenses of conglomerate on southwestern part of valley.

Marine rocks (Pre-Tertlary)-Shale, siltstone, and conglomerate. Includes Knoxville Formation (Upper Jurassic), Chico Formation (Cretaceous), and Lower Cretaceous rocks (formerly called Shasta Series, now obsolete).

Granitic rocks (Pre-Tertiary) - Chiefly granitic rocks on eastern side of valley, in some places consists of mafic intrusive rocks.

Metamorphlc rocks (Pre-Tertlary)-Metasedimentary and metavolcanic rocks, volcanic breccia, and some slate on eastern side of valley.

Current body of water.

Lake

Mine waste.

Figure 4. Continued. 


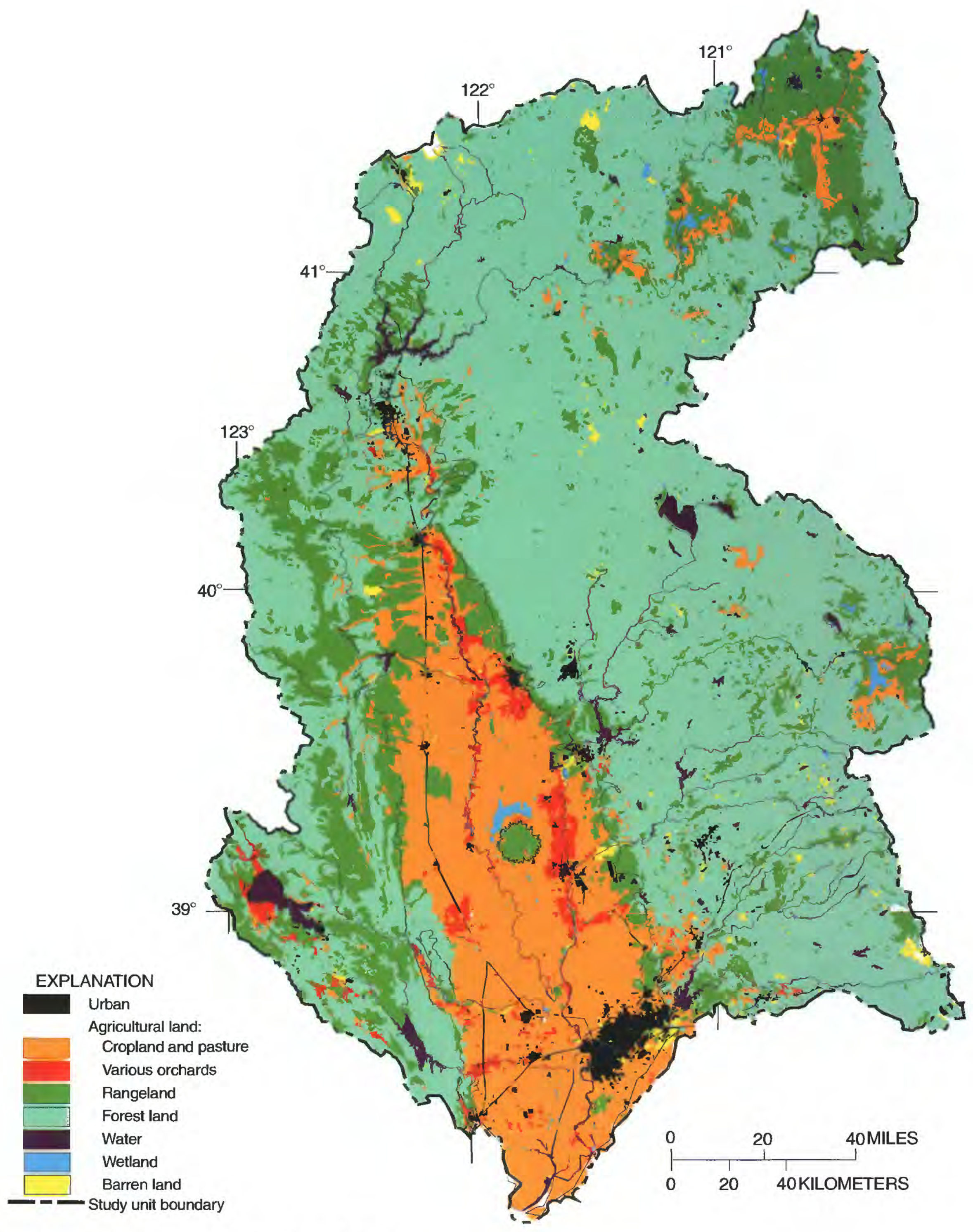

Figure 5. Land use of the Sacramento River Basin, California. 


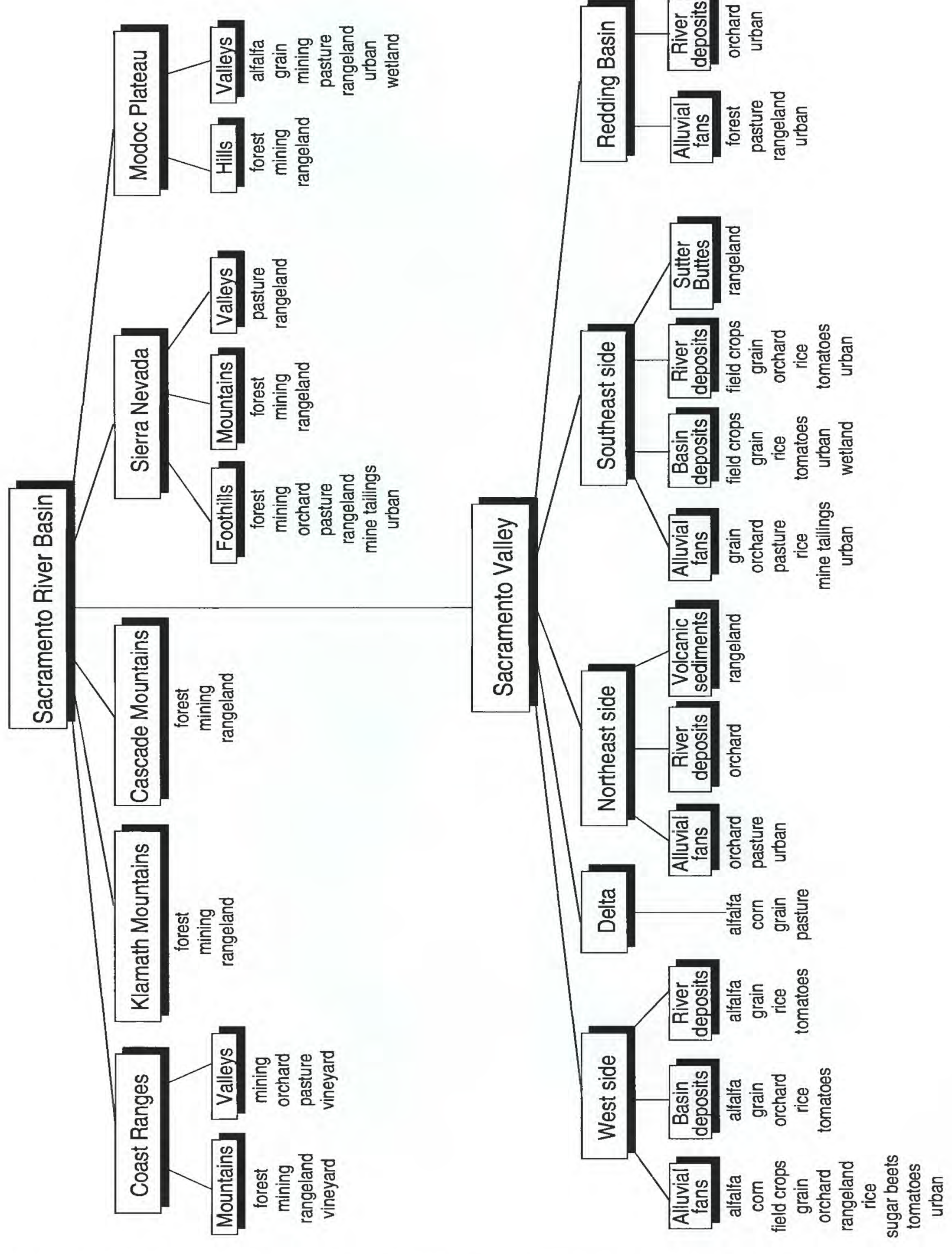

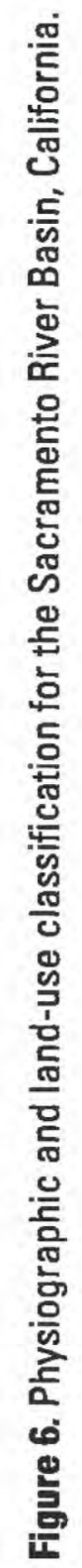




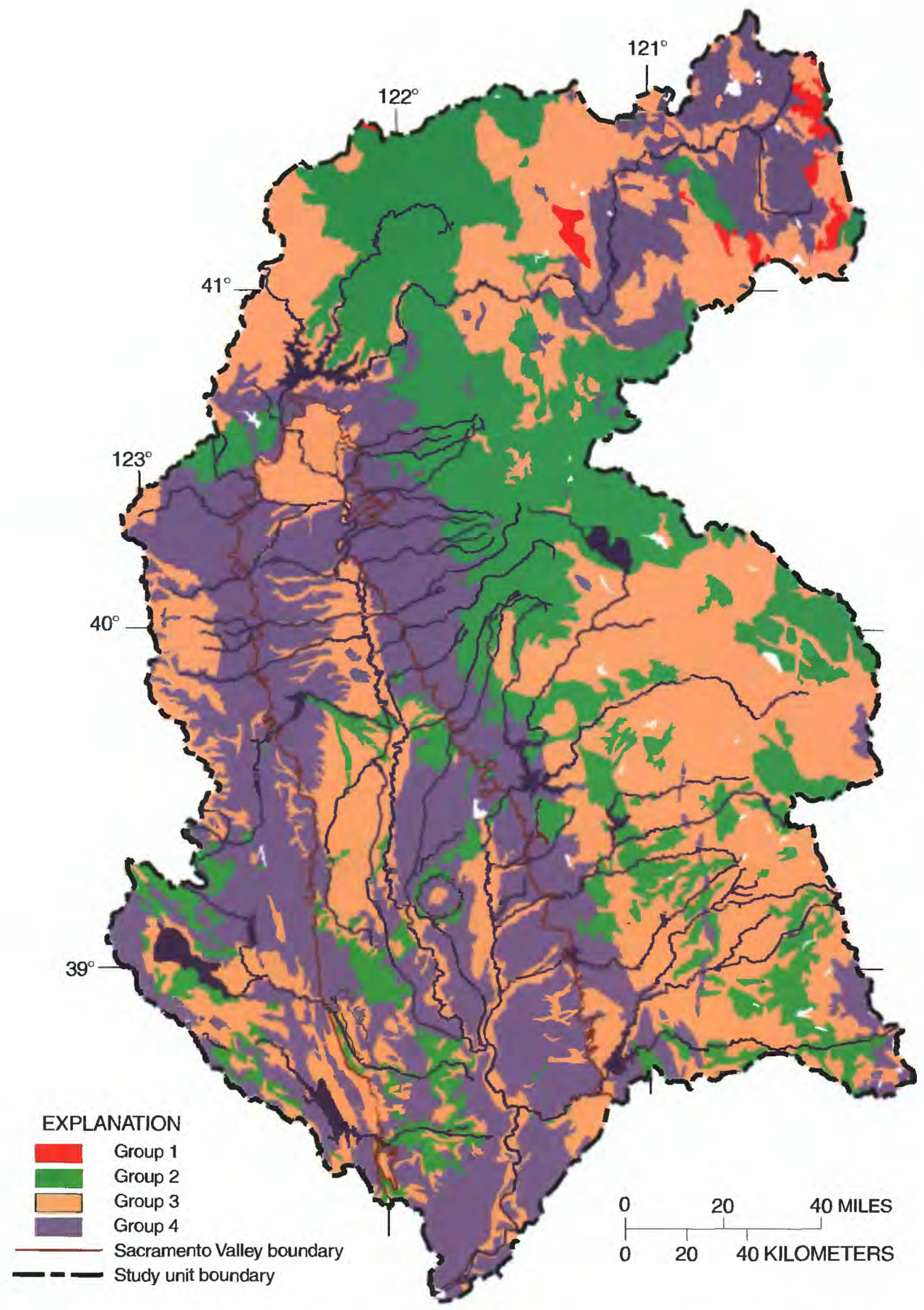

Figure 7. Soil infiltration regions of the Sacramento River Basin, California. Group 1 represents high infiltration rates; soils are deep, welldrained to excessively drained sands or gravels. Group 2 represents moderate infiltration rates; deep and moderately deep, moderately well and well drained soils of moderately fine to moderately coarse textures. Group 3 represents slow infiltration rates; soils with layers impeding downward movement of water or soils of moderately fine or fine textures. Group 4 represents very slow infiltration rates; clay soils that have high swelling potential, high water table, or shallow impervious layer. Group definitions from Soil Conservation Service (1993). 
Table 1. Water-balance plan for the Sacramento River Basin for 1990 and 2020

[Source of data: California Department of Water Resources, 1993. All average and drought figures are in thousands of acre-feet. -, no data]

\begin{tabular}{|c|c|c|c|c|}
\hline \multirow{2}{*}{ Demand and supply } & \multicolumn{2}{|c|}{1990} & \multicolumn{2}{|c|}{2020} \\
\hline & Average & Drought & Average & Drought \\
\hline \multicolumn{5}{|c|}{ Net Demand } \\
\hline Urban, with 1990 level of conservation . . . . . . . & 745 & 809 & 1,255 & 1,359 \\
\hline $\begin{array}{l}\text { Urban, reductions due to long-term conservation } \\
\text { measures. }\end{array}$ & - & - & -25 & -25 \\
\hline Agricultural $\ldots \ldots \ldots \ldots \ldots \ldots \ldots \ldots$ & 6,752 & 7,308 & 6,483 & 7,039 \\
\hline $\begin{array}{l}\text { Agricultural, reductions due to long-term } \\
\text { conservation measures. }\end{array}$ & - & - & -10 & -10 \\
\hline Environmental $\ldots \ldots \ldots \ldots \ldots \ldots \ldots \ldots$ & 3,677 & 3,283 & 4,227 & 3,833 \\
\hline Other.$\ldots \ldots \ldots \ldots \ldots \ldots \ldots \ldots \ldots$ & 474 & 408 & 438 & 398 \\
\hline Total net demand $\ldots \ldots \ldots \ldots \ldots \ldots \ldots$ & 11,649 & 11,808 & 12,368 & 12,594 \\
\hline \multicolumn{5}{|c|}{ Water Supplies with Existing Facilities } \\
\hline \multicolumn{5}{|l|}{ Developed supplies: } \\
\hline Surface water.$\ldots \ldots \ldots \ldots \ldots \ldots \ldots$ & 5,812 & 5,092 & 6,081 & 5,377 \\
\hline Ground water.$\ldots \ldots \ldots \ldots \ldots \ldots$ & 2,480 & 2,850 & 2,497 & 3,044 \\
\hline Ground water overdraft $\ldots \ldots \ldots \ldots \ldots \ldots$ & 33 & 33 & 33 & 33 \\
\hline Subtotal. $\ldots \ldots \ldots \ldots \ldots \ldots \ldots \ldots$ & 8,325 & 7,975 & 8,611 & 8,454 \\
\hline Dedicated natural flow $\ldots \ldots \ldots \ldots \ldots \ldots$ & 3,323 & 2,929 & 3,749 & 3,355 \\
\hline Total water supplies $\ldots \ldots \ldots \ldots \ldots \ldots \ldots$ & 11,648 & 10,904 & 12,360 & 11,809 \\
\hline Demand and supply balance $\ldots \ldots \ldots \ldots \ldots \ldots$ & 0 & -904 & -8 & -785 \\
\hline
\end{tabular}

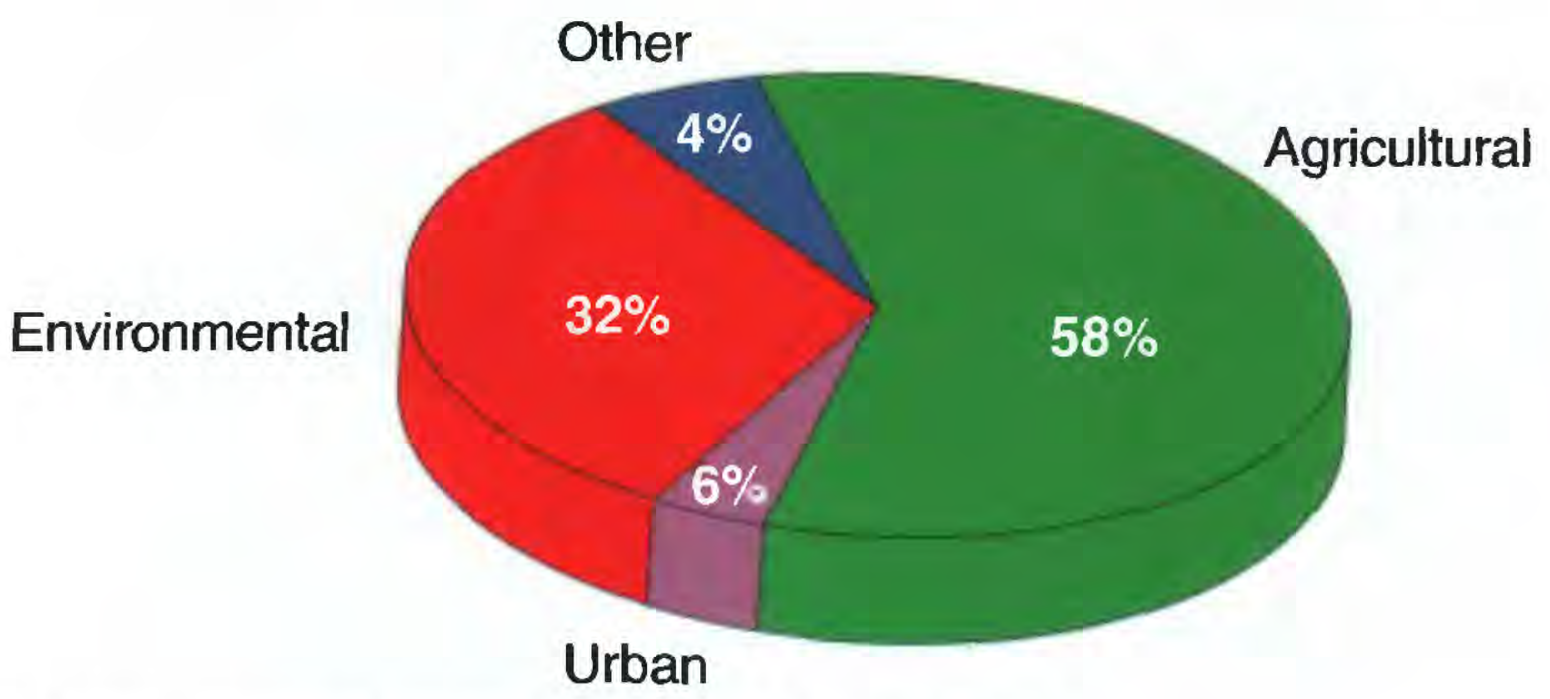

Figure 8. Water allocated for various uses in the Sacramento Valley, California, in 1990.

committee, are (1) trace metals, including mercury, copper, lead, and cadmium; (2) rice pesticides; (3) orchard pesticides; (4) urban pesticides (herbicides and insecticides); and (5) air transport of herbicides, insecticides, and other volatile organic compounds (VOC). Management of the reservoirs also affects water quality - in particular temperature - and can be especially problematic during drought years as low water flows and higher temperatures can affect reproductive success of various fish species. Nutrients have not been a major problem for the Sacramento River waterways, but nutrient concentrations in ground water are elevated in some locations. Mercury and organophosphate insecticides are two of the most problematic water quality issues for the study unit. Mercury has accumulated in fish tissue in rivers within the study unit and the San Francisco Bay (San Francisco Bay Regional Water Quality Control Board, 1995). The sources of mercury include abandoned or inactive mercury mines, residues from gold-mining 


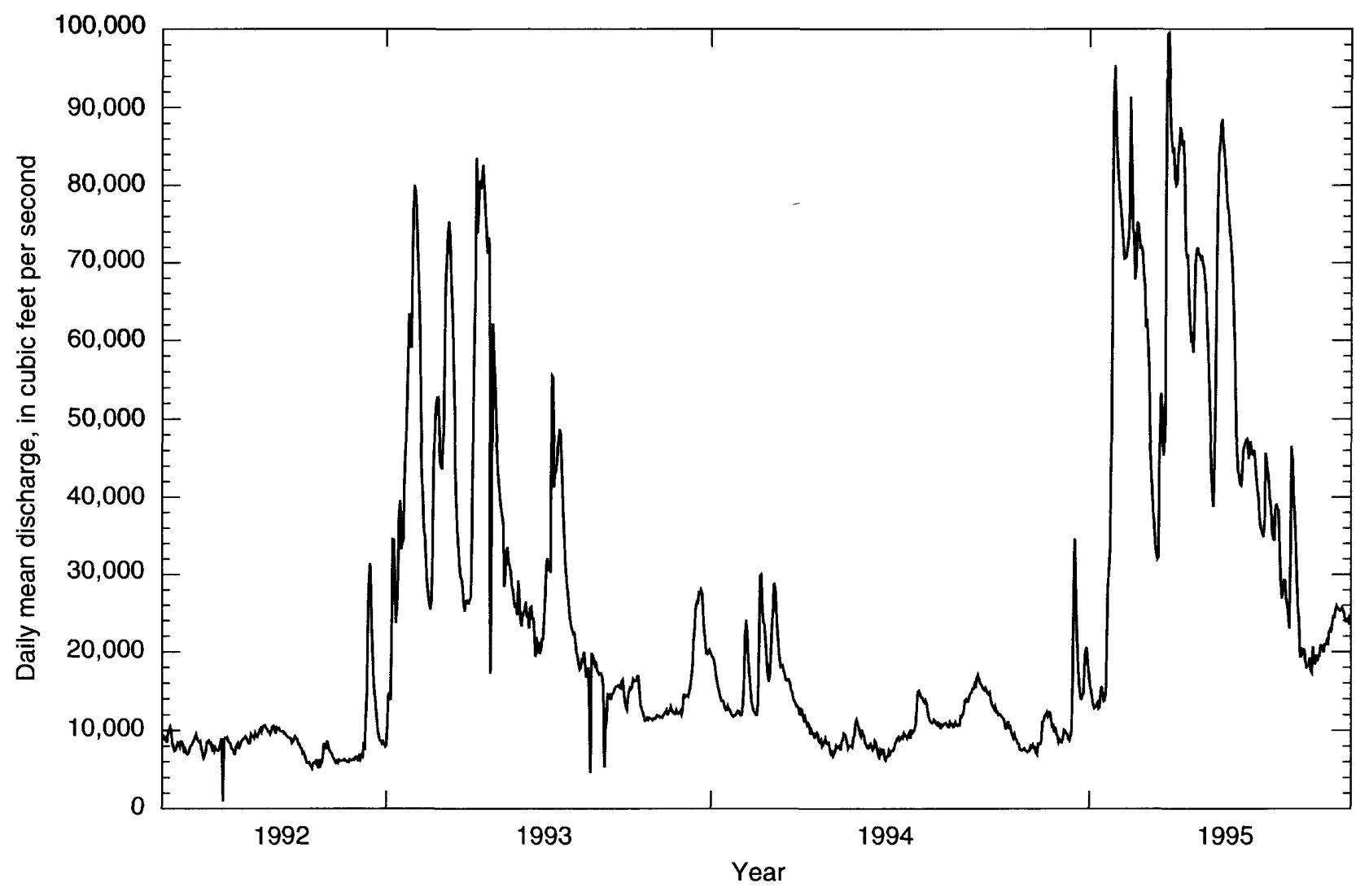

Figure 9. Daily mean discharge of the Sacramento River at Freeport, California, June 1, 1992, through September $25,1995$.

operations, geological features, and the atmosphere. Organophosphate insecticides are used in agricultural areas on a variety of crops and in urban areas for insect control. Diazinon, an organophosphate insecticide, is applied to orchard crops, such as almonds and prunes, during January and February, the period of time when some of the heaviest rainfall occurs in the Sacramento Valley. Diazinon can be mobilized to the rivers following these rainstorms and the concentrations can be sufficiently high to cause short-term toxicity to aquatic organisms, especially to invertebrates (Domagalski, 1996).

The planned surface water monitoring activities for the Sacramento River Basin will be water quality assessments of the Sacramento River and its major tributaries, including impacts of major agricultural activities, runoff from mining operations, and runoff from urban sources. Industrial sources of contaminants to the river are considered minor. The Sacramento River, below Shasta Lake, is the major water resource under investigation, and the design of the study is centered about that reach of river. The biological assessment will focus on the rivers of the Sacramento Valley. Ground water studies also will be done in the Sacramento Valley and will include water quality assessments of subunits within the study unit and the effects of specific land uses on ground water quality, especially the impacts on ground water quality from urban activities.

\section{Occurrence and Distribution Assessment Activities}

Activities for NAWQA study units are based on a rotational cycle. A timeline for the activities for each set in the cycle is shown in figure 10 . The first 2 years of each set are reserved for planning, analysis of existing data, and design, followed by a 3-year period of data collection and interpretation and a 2-year period for report writing. The last 5 years will be spent in low-level assessment activities. The cycle then starts again - water quality issues of importance are determined and new assessment plans are established. Collectively, for the first 10 -year cycle, the data 


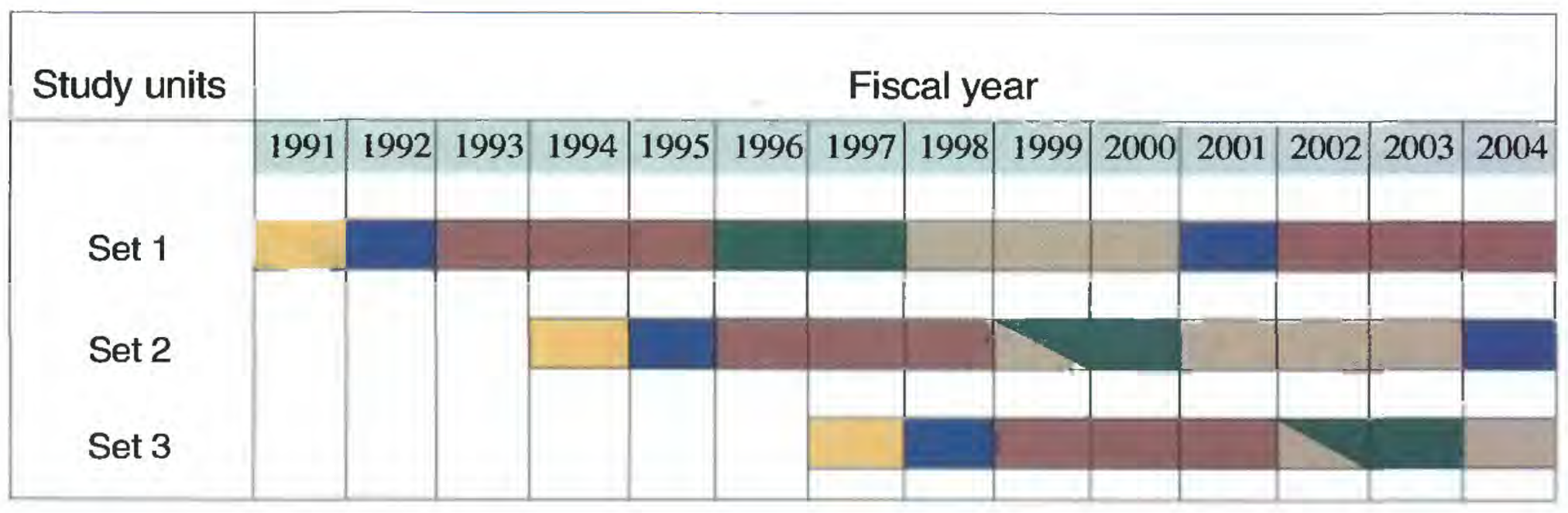

EXPLANATION

\begin{tabular}{|l}
\hline Initial planning \\
Analysis of existing data and design of studies \\
Intensive data collection and interpretation \\
Completion of primary reports \\
Low-level assessment activities
\end{tabular}

Figure 10. Timeline of National Water-Quality Assessment Program activities. Under study units, set 1 represents the 20 study units started 1991; set 2 represents the 15 study units started 1994; and set 3 represents the 15 study units began in 1997.

collection and interpretation activities for ground water and surface water, and ecology, are referred to as the Occurrence and Distribution Assessment. The individual components of the assessment are shown in figure 11.

\section{SURFACE WATER}

Investigative activities for surface water sites include the establishment of a basic and intensive fixed-site network, the sampling of river bed sediment,

\section{Occurrence and Distribution Assessment}

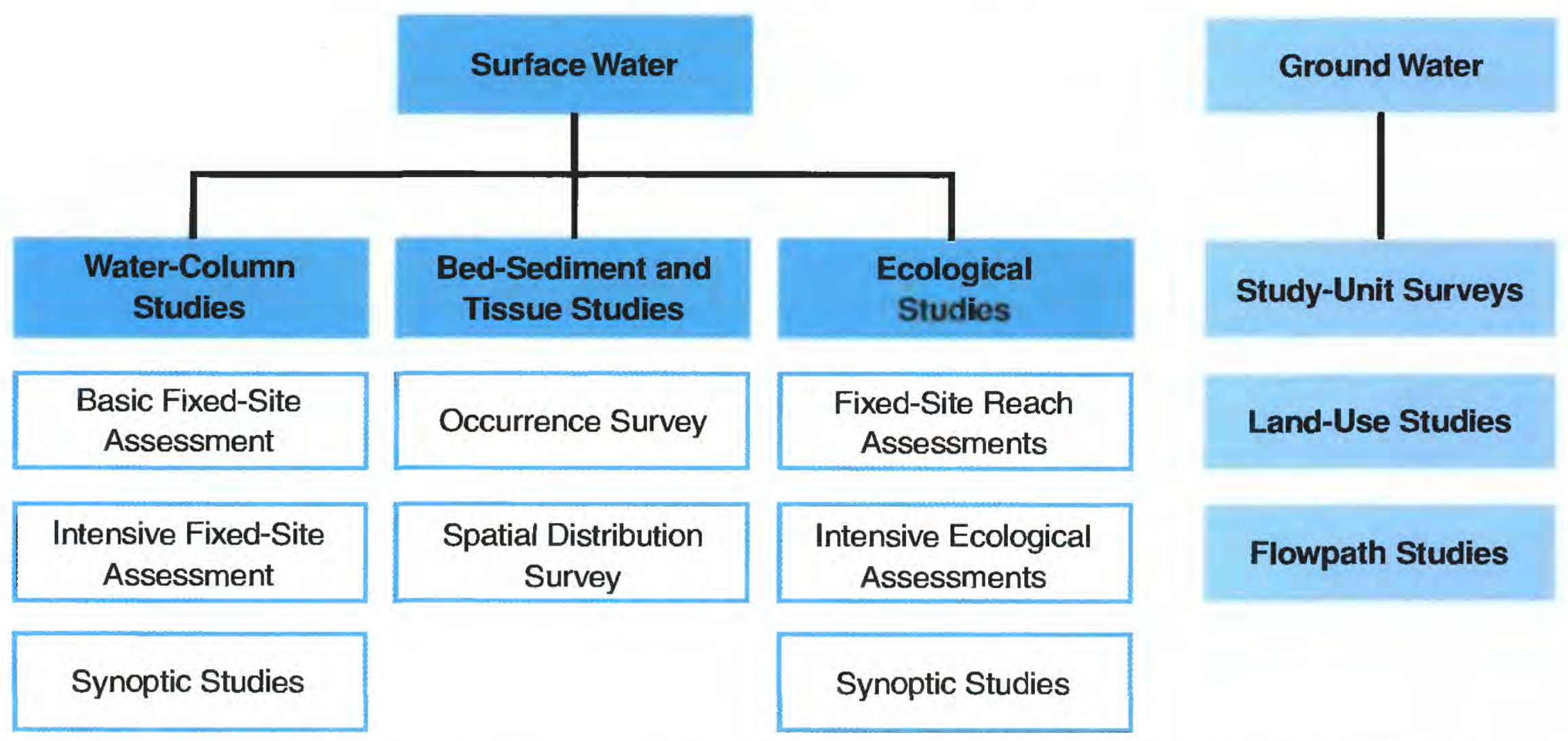

Figure 11. National Water-Quality Assessment Program components of the Occurrence and Distribution Assessment (from Gilliom and others, 1995) 
the sampling of tissue of aquatic organisms, and the completion of synoptic surveys.

\section{Basic Fixed Site Network}

Basic fixed sites are sites on streams at which streamflow is measured and samples are collected to assess the broad-scale spatial and temporal character and transport of inorganic constituents of stream water in relation to hydrologic conditions and environmental settings. Three types of water-column sampling activities - continuous monitoring, fixed-interval sampling, and extreme-flow sampling - are carried out for 2 years. Reach assessments of ecological conditions and bed-sediment and tissue sampling also are done at these sites. A subset of basic fixed sites are intensive fixed sites. Intensive fixed sites are those basic fixed sites that have increased sampling frequency (that is, more "intensive" sampling) during selected seasonal periods and analysis of dissolved pesticides and(or) volatile organic compounds for 1 year. The basic fixed-site network is composed of two general site types, each of which represents a different environmental setting for water quality conditions-indicator and integrator sites. The indicator sites are stream sampling sites located at or near the outlets of drainage basins with relatively homogeneous land use and physiographic conditions (that is, "indicative" of a specific environmental setting). The basins are chosen to be as large and representative of the given land use as possible while still encompassing primarily one environmental setting. The basin size is typically between 20 to $200 \mathrm{mi}^{2}$, but may be larger in some cases. The integrator sites are stream sampling sites located downstream of drainage basins that are large and complex and often contain multiple environmental settings (that is, "integrating" various environmental settings). Typically, these integrator sites are on major streams with drainage basins that include a substantial portion of the study unit area.

A more detailed description of how basic and intensive fixed sites are selected and defined is provided by Gilliom and others (1995). A list of the basic and intensive fixed sites is given in table 2 .

The Sacramento Valley is the dominant physiographic province in the network, and sites within the network have been chosen downstream of the major reservoirs (that is, Shasta Lake, Lake Oroville, and Folsom Lake). Surface water inputs to the major reservoirs are of high quality because their inflow consists of snowmelt, and there is little chance of water quality degradation. In fact, inorganic water quality, with respect to major elements (such as sodium and chloride), is excellent for the entire reach of the Sacramento River within the study unit.

Table 2. Sacramento River Basin National Water-Quality Assessment Program: Basic and intensive fixed sites

[Basic fixed site location: Investigative activity site. U.S. Geological Survey (USGS) site ID: Unique identification number for each site. Site type: Indicator site, stream sampling site located at or near outlets of drainage basins with homogeneous land use and physiographic conditions. Integrator site, stream sampling site located downstream of drainage basins that are large and complex. mi ${ }^{2}$, square miles]

\begin{tabular}{|c|c|c|c|c|}
\hline Basic fixed site location & $\begin{array}{l}\text { USGS } \\
\text { site ID }\end{array}$ & Site type & $\begin{array}{c}\text { Drainage } \\
\text { areas }\left(\mathbf{m i}^{2}\right)\end{array}$ & $\begin{array}{l}\text { Intensive } \\
\text { fixed sites }\end{array}$ \\
\hline $\begin{array}{l}\text { Sacramento River above Bend Bridge near Red } \\
\text { Bluff. }\end{array}$ & 11377100 & Integrator $\ldots \ldots \ldots \ldots \ldots \ldots$ & 9,120 & No \\
\hline Sacramento River at Colusa. . . . . . . . . . . & 11389500 & Integrator $\ldots \ldots \ldots \ldots \ldots$ & 12,250 & No \\
\hline Yuba River near Marysville . . . . . . . . . . & 11421000 & Integrator $\ldots \ldots \ldots \ldots \ldots \ldots$ & 1,440 & No \\
\hline Feather River near Nicolaus. . . . . . . . . . & 11425000 & Integrator $\ldots \ldots \ldots \ldots \ldots$ & 2,230 & No \\
\hline Sacramento Slough near Knights Landing . & 11391100 & Indicator (agriculture) . & 1,301 & No \\
\hline $\begin{array}{l}\text { Colusa Basin Drain at Road 99E near } \\
\text { Knights Landing. }\end{array}$ & 11390890 & Indicator (agriculture) . . . & 1,650 & Yes (pesticides) \\
\hline Sacramento River at Verona. . . . . . . . . . & 11425500 & Integrator $\ldots \ldots \ldots \ldots \ldots \ldots$ & 17,690 & No \\
\hline Cache Creek at Rumsey. . . . . . . . . . & 11451800 & Indicator (agriculture, mining) $\ldots$ & 1,139 & No \\
\hline Arcade Creek near Del Paso Heights. . . . . . & 11445360 & Indicator (urban) $\ldots \ldots \ldots \ldots \ldots$ & 33.5 & $\begin{array}{l}\text { Yes(pesticides and } \\
\text { volatile organic } \\
\text { chemicals) }\end{array}$ \\
\hline American River at Sacramento . . . . . . . & 11447000 & Integrator $\ldots \ldots \ldots \ldots \ldots$ & 2,000 & No \\
\hline Sacramento River at Freeport . . . . . . . & 11447650 & Integrator $\ldots \ldots \ldots \ldots \ldots$ & 23,000 & Yes (pesticides) \\
\hline
\end{tabular}


Sacramento River water can be characterized as having a dilute sodium-calcium-bicarbonate composition. A plot of sodium, as a function of discharge for the Freeport site, from existing USGS data is shown in figure 12. Sodium concentrations are low across a broad range of flow conditions, with a slight trend of decreasing concentrations with increasing flow (see fig. 12). However, discharge only explains 15 percent $\left(r^{2}=0.15\right)$ of the variation in sodium concentrations.

Eleven basic fixed sites have been chosen in the Sacramento Valley for the NAWQA study on the basis of the likelihood of obtaining a representative mass balance of various natural constituent loadings, and possible inputs of contaminants to the Sacramento River. The Sacramento River is the major water resource in this network, and four sites have been chosen on it because of the locations of various contaminant sources: above Bend Bridge near Red Bluff (site 1); at Colusa (site 2); at Verona (site 7); and at Freeport (site 11) (fig. 13). The drainage basins associated with sites are shown in figure 14. The site above Bend Bridge near Red Bluff (site 1), the most upstream site, is located downstream of Shasta Lake. Water quality at this site might be degraded as a result of acid mine drainage and associated metals from the Iron Mountain Mine (a U.S. Environmental Protection Agency Superfund site) from Spring Creek (fig. 1). The next site, in downstream order, is the Sacramento River at Colusa (site 2). This site should have generally good water quality because it is sufficiently downstream of Spring Creek and upstream of the major agricultural inputs. Pesticide concentrations should be relatively low at this site because most of the agricultural drainage is downstream, although some agricultural land uses exist upstream. The next site, the Sacramento River at Verona (site 7), is just downstream of the major agricultural inputs and could be affected by agricultural contaminants. The final site, at Freeport (site 11), is the downstream integrator and is also an intensive fixed site.

Three other integrator sites chosen for the basic fixed-site network are the Feather River near Nicolaus (site 4), the Yuba River near Marysville (site 3), and the American River at Sacramento (site 10). The lower

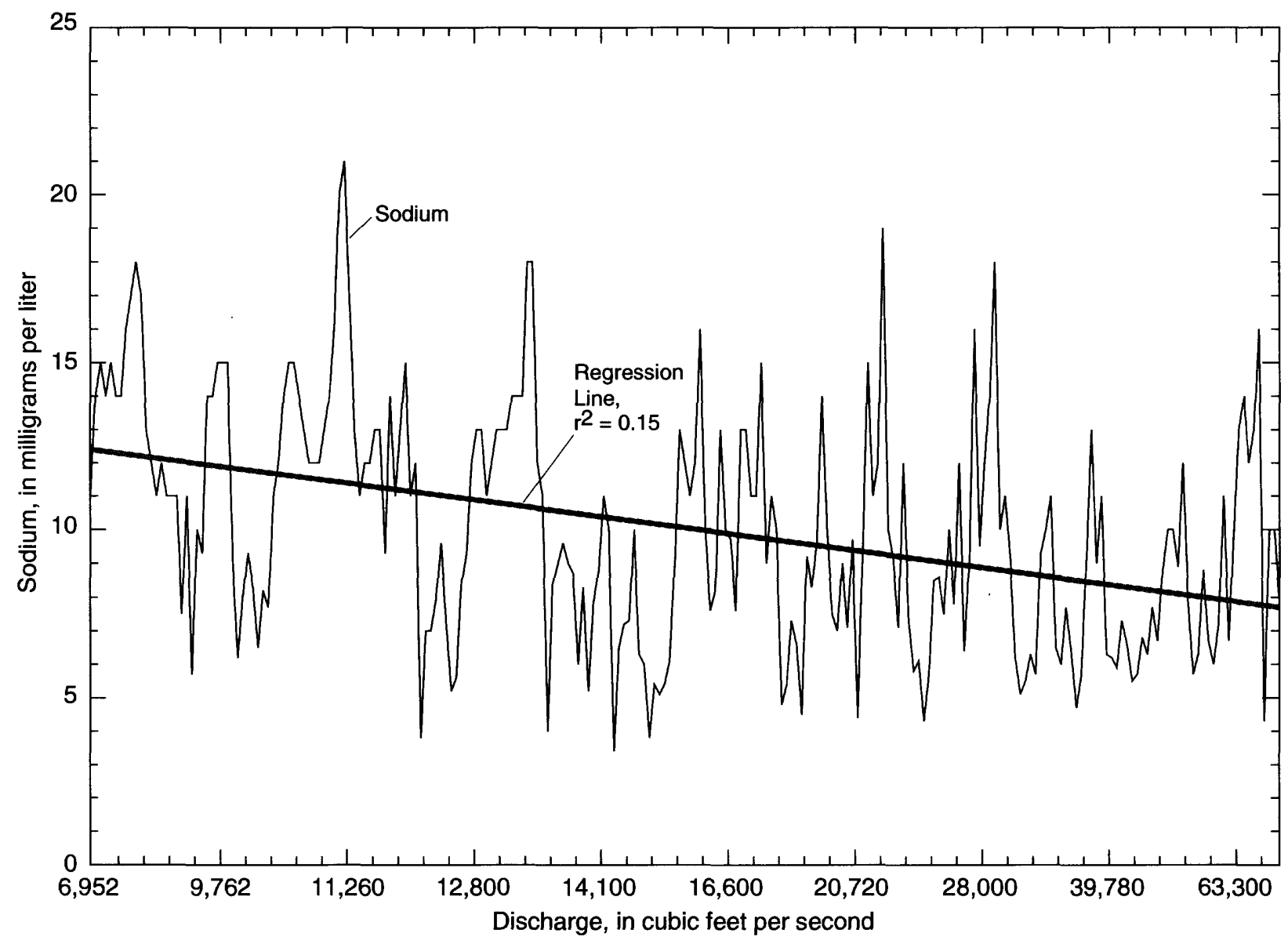

Figure 12. Plot of sodium as a function of discharge for the Sacramento River at Freeport, California. The period of record is $1960-1980$. 


\section{EXPLANATION}

Sacramento Valley

Study unit boundary

Basic fixed site (non-intensive site)

1 Sacramento River above Bend Bridge near Red Bluff

2 Sacramento River at Colusa

3 Yuba River near Marysville

4 Feather River near Nicolaus

5 Sacramento Slough near Knights Landing

7 Sacramento River at Verona

8 Cache Creek at Rumsey

10 American River at Sacramento Intensive fixed site (intensive site)

6 Colusa Basin Drain at Road 99E near Knights Landing

9 Arcade Creek near Del Paso Heights

11 Sacramento River at Freeport $x \quad$ Mining

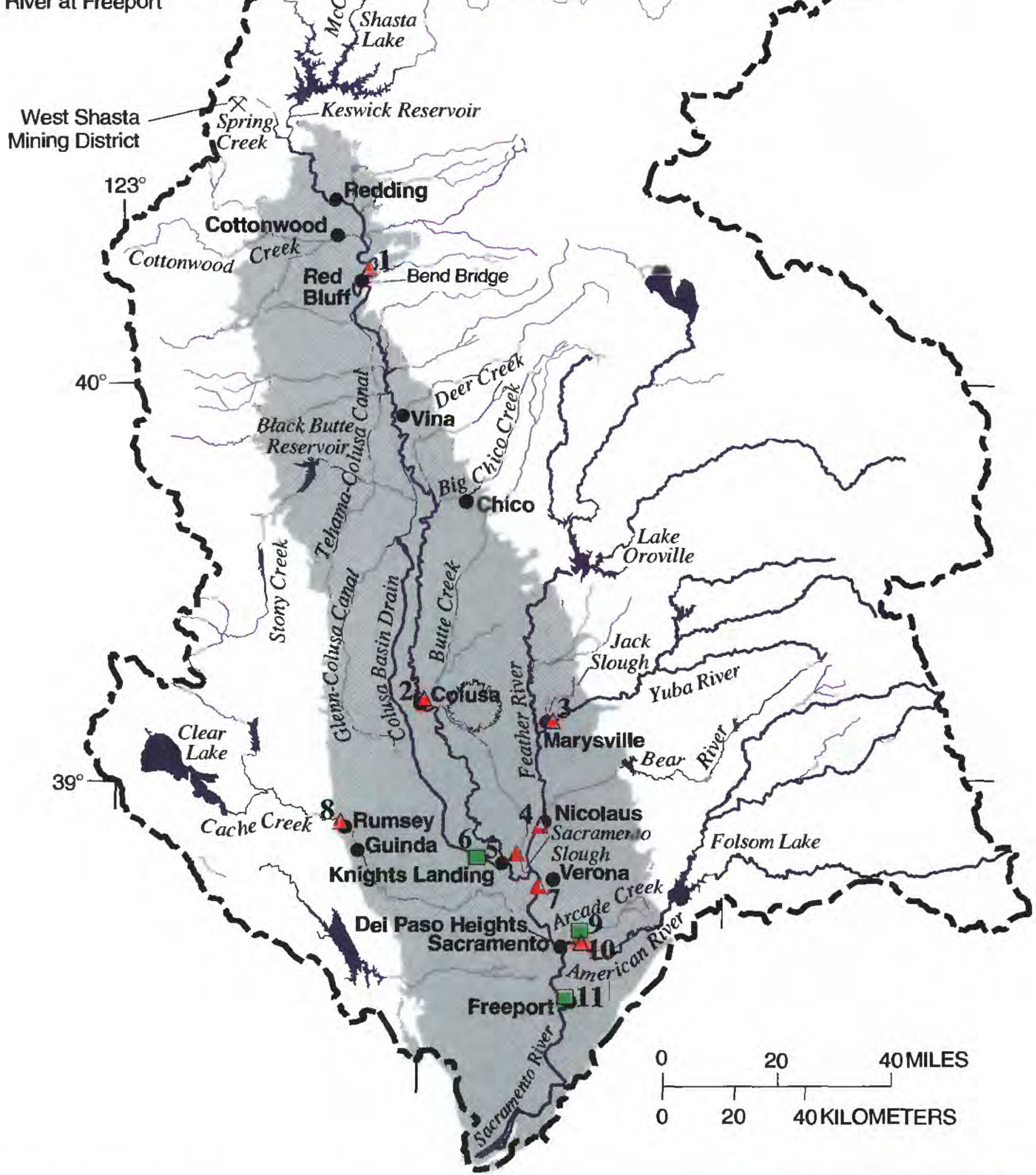

Figure 13. Basic and intensive fixed sites for the Sacramento River Basin, California, National Water-Quality Assessment Program. 
EXPLANATION

Basic and intensive fixed
sampling site

Site number Site name and associated drainage basin

1 Sacramento River above Bend Bridge near Red Bluff

2 Sacramento River at Colusa

3 Yuba River near Marysville

$4 \quad$ Feather River near Nicolaus

5 Sacramento Slough near Knights Landing

6 Colusa Basin Drain at Road 99E near Knights Landing

7 Sacramento River at Verona

8 Cache Creek at Rumsey

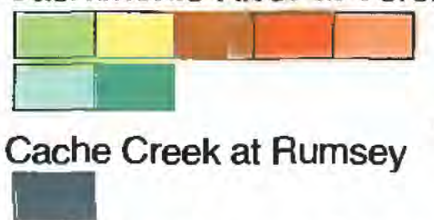

9 Arcade Creek near Del Paso Heights

10

American River at Sacramento

11 Sacramento River at Freeport
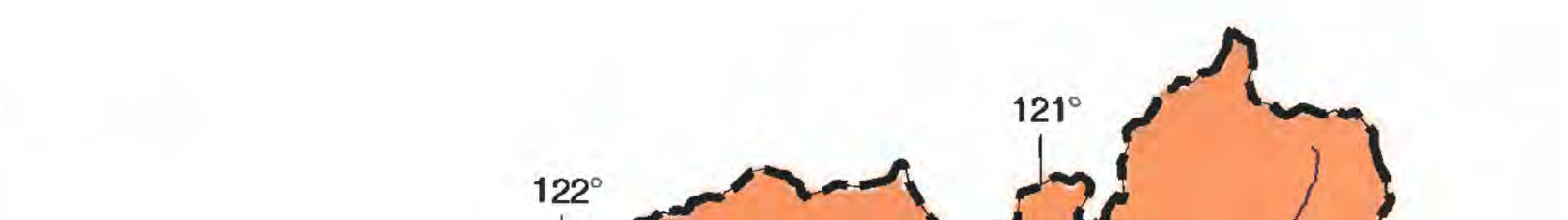
Feather River Basin has intense agricultural activity. In addition to agricultural inputs to the Feather River, metal inputs from historic gold mining activities might occur as a result of transport from the Yuba River, as well as from sources within the Feather River drainage. The American River, the other major tributary to the Sacramento River, was selected as a basic fixed site because it is a large tributary and it might be affected by urban runoff.

Four of the sites in the basic fixed-site network are indicator sites: three agricultural and one urban. Two of these are also intensive fixed sites (Colusa Basin Drain at Road 99E near Knights Landing [site 6], and Arcade Creek near Del Paso Heights [site 9]). Two of the agricultural indicator streams are the Colusa Basin Drain, which drains a major part of the western Sacramento Valley, and the Sacramento Slough, which drains a major part of the eastern Sacramento Valley. Rice is the major crop in each drainage. Other agricultural land uses include growing row and orchard crops and grazing. The major pesticides anticipated to be detected at these indicator sites are carbofuran, chlorpyrifos, diazinon, methidathion, metolachlor, molinate, simazine, and thiobencarb. Cache Creek at Rumsey (site 8) also is an agricultural indicator, but was chosen mainly because it is a potential source of mercury, from mercury mines in the Coast Ranges, to the lower Sacramento Valley and San Francisco Bay. Arcade Creek near Del Paso Heights (site 9), which has its source and outflow entirely within the city and county of Sacramento, was selected as an urban indicator because the flow is entirely urban runoff and the inputs to the creek have been mapped. The site at Arcade Creek near Del Paso Heights (site 9) is an intensive fixed site for VOCs and pesticides. Past sampling by the California Regional Water Quality Control Board (CRWQCB) has shown that elevated levels of toxic contaminants, such as diazinon, occur in the stream and that some of this diazinon probably is the result of atmospheric transport (Valerie Connor, California Regional Water Quality Control Board, oral commun., 1995).

Sampling at the basic fixed site network, which began in February 1996, will run for at least 2 years. Water quality samples collected at basic fixed sites are tested for major cations and anions, nutrients, dissolved and suspended organic carbon, $\mathrm{pH}$, alkalinity, specific conductance, and dissolved oxygen. This same suite of constituents, plus pesticides or VOCs, are analyzed at intensive fixed sites. In addition to the previously described constituents, all samples collected at basic fixed sites will be analyzed for dissolved metals because metals are a major water quality concern in the study unit. The sampling and testing of dissolved metals is intended to demonstrate the temporal and spatial variability in concentration at these sites, especially with respect to standards or water quality goals set by the State of California.

Sampling for VOCs and pesticides will be completed within 2 years beginning in February 1996 at Arcade Creek near Del Paso Heights. The frequency of sampling for VOCs and pesticides has been twice monthly; in addition, storm samplings will be included. Sampling for pesticides at the agricultural indicator sites, which began in December 1996, will continue for 1 year. The intensive fixed-site sampling for pesticides will consist only of twice monthly samplings during the rice growing season and monthly during the rest of the year. Storm samplings for pesticides at the agricultural intensive fixed site will also be completed.

Water will be collected for mercury analyses at the basic and intensive fixed sites. The analyses will include total mercury at all sites and methyl mercury at five sites. The sampling for mercury is designed to determine the variation in total mercury concentrations at these sites during the year and to test whether processes occurring in the Sacramento Valley, specifically rice production, contribute to the production of methyl mercury. Methyl mercury is known to form in wetland environments (Zilloux and others, 1993). Rice production requires seasonal flooding and, therefore, the creation of artificial wetlands. The irrigation water used for rice production is present in the rice fields from May to September. This irrigation water is discharged to agricultural drains during May to September. One site, the Sacramento River at Colusa (site 2), is above most of the areas where rice field drainage enters the river and will be used as a control site for methyl mercury. Methyl mercury concentrations are not expected to vary significantly throughout the year at that site. The Sacramento River at Verona (site 7) is just downstream of the major inputs of rice field drainage to the river. Two major agricultural drains, the Colusa Basin Drain and the Sacramento Slough, transport most of the rice field drainage of the Sacramento Valley to the Sacramento River. Finally, the concentration of methyl mercury at the farthest downstream integrator site-the Sacramento River at Freeport (site 11) -also will be measured. 


\section{Water Chemistry Synoptic Surveys}

Synoptic surveys are short-term investigations of water quality during selected seasonal periods or during certain hydrologic conditions (Gilliom and others, 1995). Water chemistry synoptic surveys are planned for pesticides, VOCs, trace metals, and sediment-hosted contaminants (primarily metals).

Storm samplings for agricultural pesticides associated with orchards have been completed by the USGS Toxic Substances Hydrology Program and by the CRWQCB (Kuivila and Foe, 1995). Both programs showed that pesticides, primarily chlorpyrifos, diazinon, methidathion, and some herbicides, are transported during winter storms. Diazinon was the most frequently detected pesticide and the one present in the highest concentrations. The sources of the pesticides are orchards in the Feather River drainage, the Sacramento Slough drainage, and possibly the drainage basins of tributaries to the Sacramento River upstream of Colusa. Because of the continued application of agricultural pesticides in the orchards, it is expected that diazinon will continue to be detected in future storm-water runoff samplings. Those samplings are planned for January-February 1998.

Pesticides and VOCs in urban storm runoff have not been well characterized, but it is known that concentrations sufficiently high as to be toxic to aquatic organisms occur in Arcade Creek near Del Paso Heights (site 9) water based on reconnaissance sampling. Sampling pesticides and VOCs in, as well as inputs to Arcade Creek near Del Paso Heights (site 9), will be difficult because of the extremely rapid changes in flow in these urban drains following storms. Therefore, it is anticipated that an automatic sampler, capable of sampling pesticides and VOCs, will be installed for the collection of those samples following storms.

Mercury transport during and following storms and mercury transformation processes are considered critical issues by the Sacramento NAWQA liaison committee. Synoptic surveys for mercury will address the spatial variability in concentrations within the Sacramento River during low- and high-flow conditions. These studies on mercury transport are scheduled in addition to the monthly sampling at basic fixed sites.

\section{BIOLOGY AND ECOLOGY}

\section{Bed Sediment and Tissue Sampling}

Bed sediment and tissue (from fish and other aquatic animals) will be sampled to help assess the occurrence and distribution of trace elements and hydrophobic organic contaminants in streams. An Occurrence Survey is designed to provide an initial identification of important constituents on the basis of data from a few sites. A Spatial Distribution Survey, if completed, will improve geographic coverage for priority constituents through broader areal sampling and improved resolution in priority areas. The design of the Spatial Distribution Survey will be determined by results of the Occurrence Survey (Gilliom and others, 1995). Sites for the bed sediment and tissue occurrence survey include the 11 basic and intensive fixed sites and 6 additional sites (fig. 15). These sites were sampled during October and November 1995. The sampling can take place only during the autumn months when the lowest discharge occurs on the Sacramento River and its tributaries. The sites include three reference sites: McCloud River above Shasta Lake, Cottonwood Creek near Cottonwood, and Deer Creek near Vina. The McCloud River site, north of Shasta Lake, should be relatively unaffected by anthropogenic contaminant inputs. The Cottonwood Creek near Cottonwood site was selected as a reference site for the western valley because only a limited amount of agricultural activity is upstream of the site. The Deer Creek near Vina site, downstream from a natural and scenic area and upstream from valley agriculture, is a reference site for the eastern part of the valley. The Stony Creek below Black Butte Reservoir site, another agricultural indicator of the western valley, also is an indicator of potential sources of mercury to the Sacramento River from the western part of the valley. Two agricultural indicator sites of the eastern valley-Bear River near Highway 70 and Jack Slough at Jack Slough Road-were selected. The Bear River is also a potential source of mercury to the Feather River drainage and, ultimately, to the Sacramento River. The sites and targeted taxa are shown in table 3. Selection of taxa was a function of what organisms were present, as seen from stream reconnaissance work and specific guidelines described in protocols written for the NAWQA Program. The Asian clam, Corbicula fluminea, always was selected 


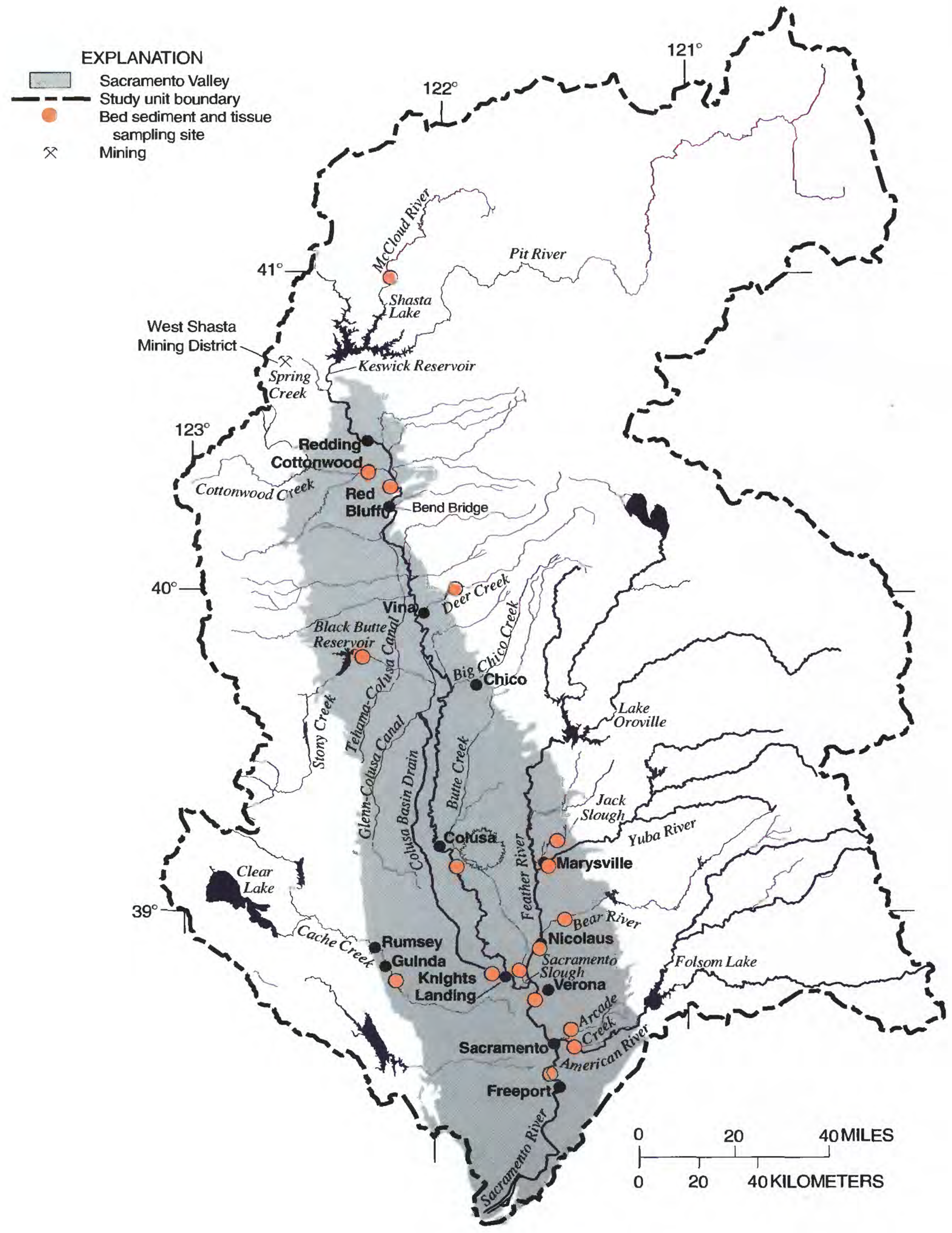

Figure 15. Bed sediment and tissue (from fish and aquatic animals) sampling sites for the Sacramento River Basin, California, National Water-Quality Assessment Program. 
Table 3. Bed sediment and tissue (from fish and aquatic animals) sampling sites of the Sacramento River Basin

[Site: Location of sites shown in figures 1 and 15. Type of site: Indicator site, stream sampling site located at outlets of drainage basins with homogeneous land use and physiographic conditions. Integrator site, stream sampling site located downstream of drainage basins that are large and complex]

\begin{tabular}{|c|c|c|c|}
\hline Basic fixed site location & Site type & $\begin{array}{l}\text { Type of tissue } \\
\text { collected }\end{array}$ & Number of samples collected \\
\hline $\begin{array}{l}\text { McCloud River above Shasta } \\
\text { Lake }\end{array}$ & $\begin{array}{l}\text { Biological and long- } \\
\text { term trend site }\end{array}$ & Sculpin & $\begin{array}{l}1 \text { tissue for metals; } 1 \text { sediment for metals; } 1 \text { tissue for organic } \\
\text { compounds; } 1 \text { sediment for organic compounds. }\end{array}$ \\
\hline $\begin{array}{l}\text { Cottonwood Creek near } \\
\text { Cottonwood }\end{array}$ & Indicator (agriculture) & $\begin{array}{l}\text { Sacramento } \\
\text { sucker }\end{array}$ & $\begin{array}{l}1 \text { tissue for metals; } 1 \text { sediment for metals; } 1 \text { tissue for organic } \\
\text { compounds; } 1 \text { sediment for organic compounds. }\end{array}$ \\
\hline $\begin{array}{l}\text { Sacramento River above Bend } \\
\text { Bridge near Red Bluff }\end{array}$ & Integrator & None & 1 sediment for metals; 1 sediment for organic compounds. \\
\hline Deer Creek near Vina & $\begin{array}{l}\text { Biological reference } \\
\text { site }\end{array}$ & Sculpin & $\begin{array}{l}1 \text { tissue for metals; } 1 \text { sediment for metals; } 1 \text { tissue for organic } \\
\text { compounds; } 1 \text { sediment for organic compounds. }\end{array}$ \\
\hline $\begin{array}{l}\text { Stoney Creek below Black Butte } \\
\text { Reservoir }\end{array}$ & Indicator (agriculture) & $\begin{array}{c}\text { Sacramento } \\
\text { sucker or } \\
\text { Corbicula }\end{array}$ & $\begin{array}{l}1 \text { tissue for metals; } 1 \text { sediment for metals; } 1 \text { tissue for organic } \\
\text { compounds; } 1 \text { sediment for organic compounds. }\end{array}$ \\
\hline Sacramento River at Colusa & Integrator & Corbicula & $\begin{array}{l}3 \text { tissue for metals; } 3 \text { sediment for metals; } 1 \text { tissue for organic } \\
\text { compounds; } 1 \text { sediment for organic compounds. }\end{array}$ \\
\hline Jack Slough at Jack Slough Road & Indicator (agriculture) & Corbicula & $\begin{array}{l}1 \text { tissue for metals; } 1 \text { sediment for metals; } 1 \text { tissue for organic } \\
\text { compounds; } 1 \text { sediment for organic compounds. }\end{array}$ \\
\hline Yuba River near Marysville & Integrator & $\begin{array}{l}\text { Sculpin and } \\
\text { Corbicula }\end{array}$ & $\begin{array}{l}2 \text { tissue for metals; } 1 \text { sediment for metals; } 2 \text { tissue for organic } \\
\text { compounds; } 1 \text { sediment for organic compounds. }\end{array}$ \\
\hline Bear River near Highway 70 & $\begin{array}{l}\text { Indicator (agricul- } \\
\text { ture, mining) }\end{array}$ & $\begin{array}{l}\text { Sacramento } \\
\text { sucker }\end{array}$ & $\begin{array}{l}1 \text { tissue for metals; } 1 \text { sediment for metals; } 1 \text { tissue for organic } \\
\text { compounds; } 1 \text { sediment for organic compounds. }\end{array}$ \\
\hline $\begin{array}{l}\text { Sacramento Slough near Knights } \\
\text { Landing }\end{array}$ & Indicator (agriculture) & Carp & $\begin{array}{l}1 \text { tissue for metals; } 1 \text { sediment for metals; } 1 \text { tissue for organic } \\
\text { compounds; } 1 \text { sediment for organic compounds. }\end{array}$ \\
\hline Feather River near Nicolaus & Integrator & Corbicula & $\begin{array}{l}1 \text { tissue for metals; } 1 \text { sediment for metals; } 1 \text { tissue for organic } \\
\text { compounds; } 1 \text { sediment for organic compounds. }\end{array}$ \\
\hline Cache Creek at Guinda & $\begin{array}{l}\text { Indicator (agricul- } \\
\text { ture, mining) }\end{array}$ & $\begin{array}{c}\text { Sacramento } \\
\text { sucker and } \\
\text { Corbicula }\end{array}$ & $\begin{array}{l}3 \text { tissue for metals; } 1 \text { sediment for metals; } 1 \text { tissue for organic } \\
\text { compounds; } 1 \text { sediment for organic compounds. }\end{array}$ \\
\hline $\begin{array}{l}\text { Colusa Basin Drain at Road 99E } \\
\text { near Knights Landing }\end{array}$ & Indicator (agriculture) & Carp & $\begin{array}{l}1 \text { tissue for metals; } 3 \text { sediment for metals; } 1 \text { tissue for organic } \\
\text { compounds; } 1 \text { sediment for organic compounds. }\end{array}$ \\
\hline Sacramento River at Verona & Integrator & Corbicula & $\begin{array}{l}\text { I tissue for metals; } 1 \text { sediment for metals; } 1 \text { tissue for organic } \\
\text { compounds; } 1 \text { sediment for organic compounds. }\end{array}$ \\
\hline $\begin{array}{l}\text { Arcade Creek near Del Paso } \\
\text { Heights }\end{array}$ & $\begin{array}{l}\text { Indicator } \\
\text { (urban) }\end{array}$ & Corbicula & $\begin{array}{l}1 \text { tissue for metals; } 1 \text { sediment for metals; } 1 \text { tissue for organic } \\
\text { compounds; } 1 \text { sediment for organic compounds. }\end{array}$ \\
\hline American River at Sacramento & Integrator & $\begin{array}{l}\text { Corbicula and } \\
\text { Sacramento } \\
\text { sucker }\end{array}$ & $\begin{array}{l}3 \text { tissues for metals; } 1 \text { sediment for metals; } 1 \text { tissue for organic } \\
\text { compounds; } 1 \text { sediment for organic compounds. }\end{array}$ \\
\hline Sacramento River at Freeport & Integrator & Corbicula & $\begin{array}{l}1 \text { tissue for metals; } 1 \text { sediment for metals; } 1 \text { tissue for organic } \\
\text { compounds; } 1 \text { sediment for organic compounds. }\end{array}$ \\
\hline
\end{tabular}


if present because it was a priority taxon for the NAWQA Program. If Corbicula were not found, other taxa were sampled, such as Sacramento sucker, catfish, or sculpin. Four sites were sampled for two taxa to determine the consequences of selecting different taxa on data interpretation. Samples for trace elements and organic contaminants were collected at all sampling sites.

\section{Ecological Issues Within the Sacramento River Basin}

A major factor that has affected aquatic communities in the Sacramento River Basin is habitat modification. The Sacramento River and most of its tributaries are modified by dams or diversions. Habitat modifications affect the temperature, nutrient load, and riparian and in-stream habitat in the Sacramento River Basin to the extent that it affects the aquatic communities. Temperature alterations can cause direct stress to aquatic organisms or can provide an environment suitable only for the more temperature-tolerant species. Another major factor that may be affecting aquatic communities in the smaller Sierran and Coast Ranges tributaries is off-stream diversion of water for consumption. Continual runoff into these streams is needed to maintain native populations and biodiversity, and to provide habitat for spawning fish species.

The National Marine Fisheries Service and the U.S. Fish and Wildlife Service are required to preserve populations of the endangered winter run Chinook salmon, as well as the spring run Chinook salmon, which is a species of special concern. The Central Valley Improvement Act federally mandates that habitat should be restored to increase the populations of Chinook salmon, steelhead, stripped bass, American shad, and white and green sturgeon, to levels at least twice the mean estimated natural production for the baseline period (1967-1991) in the Sacramento River and other rivers (for example, the San Joaquin River in the San Joaquin Valley). The delta smelt is a threatened species in the SacramentoSan Joaquin Delta that requires specific flows and water quality from the Sacramento and San Joaquin Rivers to maintain their population.

Sources of contaminants that affect aquatic communities within the Sacramento River Basin are acid mine drainage, agricultural runoff, mercury inputs, and municipal nonpoint source pollution. Acid mine drainage from Iron Mountain Mine in the northern part of the study unit introduces metal contaminants during high flows directly into the Sacramento River from Spring Creek. Just downstream of this site is the spawning area for the endangered winter run Chinook salmon. Mercury contamination of fish is of particular concern, especially in the lower Sacramento River and the San Francisco Bay. The Toxic Substance Monitoring Program of the California State Water Resources Control Board (1990) showed elevated levels of mercury in samples collected from the American River, the Feather River, the Yuba River, and Cache Creek. Runoff from orchards, rice fields, pasture, and other crops have been known to contribute agricultural chemicals to the Sacramento River and its tributaries, thereby providing a source of contaminants to the aquatic ecosystem. Several inputs of effluent from treatment plants and municipal sources up and down the Sacramento River also can affect the aquatic communities.

\section{Ecological Surveys of the Sacramento River Basin}

Ecological surveys are used to assess water quality. Information on biological communities and habitat characteristics contributes to the conceptual model of factors that affect water quality and to improved understanding of the relations among physical, chemical, and biological characteristics of streams. These surveys integrate impacts over time. Ecological assessments of stream reaches were completed at the following sites during the summer of 1996: Sacramento River at Colusa, Feather River near Nicolaus, Yuba River near Marysville, American River at Sacramento, Sacramento Slough near Knights Landing, Colusa Basin Drain at Road 99E near Knights Landing, Arcade Creek near Del Paso Heights, Cache Creek at Guinda, Deer Creek near Vina, McCloud River above Shasta Lake, and Big Chico Creek above and below Chico. The Deer Creek near Vina and McCloud River above Shasta Lake sites serve as reference sites. The McCloud River above Shasta Lake site also will be used to identify long-term trends in aquatic communities that have not been significantly disturbed by anthropogenic impact. Big Chico Creek runs through a relatively small urban area and may show the effect of urbanization on aquatic communities. The basic and intensive fixed sites that were not included for ecological assessment are the Sacramento River above Bend Bridge near Red Bluff 
(site 1), Sacramento River at Verona (site 7), and Sacramento River at Freeport (site 11) sites. At the Sacramento River sites, limits are put on sampling to prevent harm to endangered species. Therefore, only one site was chosen for ecological assessment, the Sacramento River at Colusa (site 2). Multiple-reach and multiple-year studies will be completed at the Deer Creek near Vina, McCloud River above Shasta Lake, and Cache Creek at Guinda sites.

Fish communities, invertebrates, and algae will be sampled, and habitat characterization will be done, at ecological assessment sites. Continuous temperature recording devices have been installed at all sites where ecological studies have been done or are in progress.

An ecological synoptic survey will be completed during the summer of 1997 . The streams to be sampled include Deer Creek, Big Chico Creek, Butte Creek, and the McCloud River. Sampling sites will be selected at the foothill and valley locations. Invertebrates and algae will be sampled, fish communities will be characterized, and habitat assessments will be made.

\section{GROUND WATER}

Ground water investigations under NAWQA consist of study-unit, land-use, and flow-path studies (Gilliom and others, 1995). Land-use studies target specific anthropogenic activities, such as agriculture or urban use. The goal is to relate the quality of recently recharged shallow ground water to the overlying land use. Study-unit surveys consist of sampling randomly selected wells throughout a study unit or in subdivisions (subunits) of a study unit to assess the ground water quality of the aquifers that are used for water supply. Flow-path studies are undertaken to determine processes that affect water quality in a specific section of an aquifer.

\section{Land-Use Studies}

Potential regions for land-use studies are shown in figure 16. Urban and agricultural land uses are targeted for water quality sampling.

\section{Urban Land Use}

Sacramento was selected for an urban land-use study because it has the largest population density in the study unit. Its hydrogeologic framework consists of heterogeneous alluvial deposits. Shallow ground water occurs at a wide range of depths, from near surface along the rivers to more than $150 \mathrm{ft}$ in pumping depressions and along the valley edge. Perched water tables are known to exist in the area. The unsaturated zone in most of the Sacramento area is moderately to highly impermeable. Deposits along the Sacramento and American Rivers are permeable at the surface. Shallow ground water possibly is connected to surface waters used for public supply, but is not thought to be connected to deeper ground water used for public supply. No previous studies of shallow ground water have been done in the Sacramento area, except by private consultants at sites of point-source contamination, including two United States Air Force bases and one aerospace manufacturing facility; findings of these studies have not been released. VOCs have not been reported in the shallow ground water system nor in the deeper ground water used for drinking water in the Sacramento area, except in connection with known point sources. Moderate levels of arsenic and high levels of manganese have been detected in some areas, generally associated with low redox potential of the ground water. Pesticides and high levels of radon also have been detected in some wells in the area. A total of 30 wells will be installed within the Sacramento metropolitan area.

\section{Agricultural Land Use}

A rice land-use study was chosen because rice has the largest acreage of agricultural land use in the Sacramento study unit. The rice pesticide bentazon, in use until the late 1980s, has been detected in wells in some rice areas, whereas other rice pesticides, such as carbofuran, molinate, and thiobencarb, were not detected in the same wells. Bentazon use was banned approximately 6 years ago because it was detected in ground water.

Rice fields generally are located on basin deposits and fine-grained alluvial deposits along the Sacramento River. Shallow ground water generally occurs within $20 \mathrm{ft}$ of the land surface. The three main areas of rice production will be divided into 30 equal areas (approximately 10 wells per area), and 30 randomly located sites will be selected for monitoring well installation. 


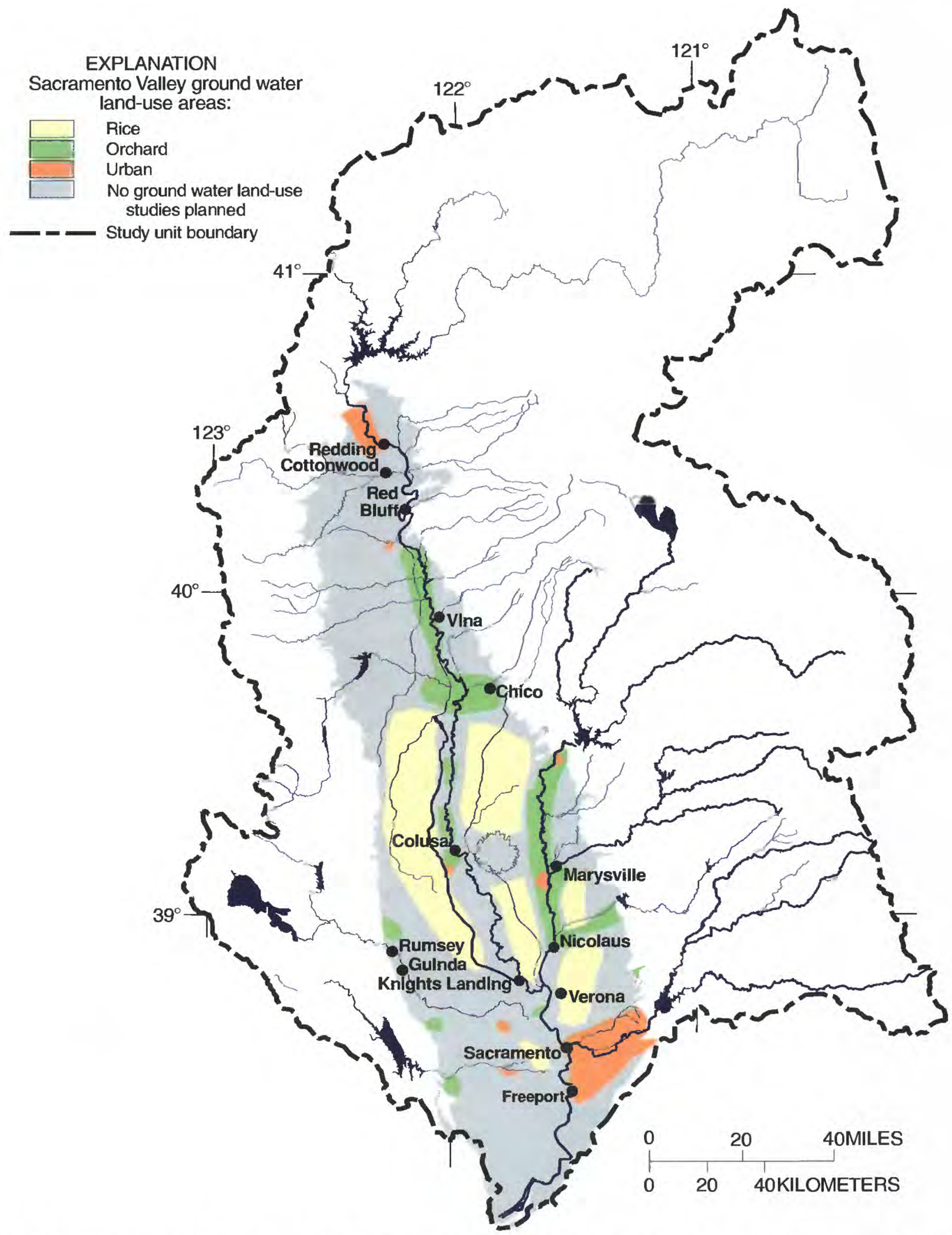

Figure 16. Candidate settings for ground water land-use studies for the Sacramento River Basin, California, National Water-Quality Assessment Program. 
Subunit Surveys

Subunit surveys are designed to evaluate the distribution of contaminants in the highly used parts of aquifers. Existing wells will be sampled. Six subunits have been delineated in the Sacramento River Basin on the basis of geomorphology and the geology of alluvial deposits (fig. 17). The subunits have been prioritized by ground water use and population data.

\section{Sacramento}

The Sacramento subunit, which includes the deposits on the southeastern side of the Sacramento Valley, has both the largest total ground water use and the largest population in the study unit. The valley aquifer in this subunit consists principally of heterogeneous alluvial fans deposited by streams draining the Sierra Nevada to the east and interfingering to the west with flood basin and channel deposits of the Sacramento River. In the northwestern part of the subunit, volcanic formations of the relict Sutter Buttes Volcano (fig. 1) intrude the alluvial valley deposits, and deeper alluvial deposits are tilted upward around the volcanic formations. At the surface, alluvial fans from the eroded volcano surround the buttes and interfinger with the alluvial deposits from the Sierra Nevada to the east and the Sacramento River to the west. Water levels range from near surface along the rivers, to greater than $150 \mathrm{ft}$ below land surface in pumping depressions and along the valley edge.

Thirty randomly selected existing (lowproduction, relatively short-screened) domestic wells, and possibly some observation wells, will be sampled. Wells that were sampled by the USGS and the California Department of Water Resources in the 1970s and 1980s-if sampling protocols are comparable to NAWQA protocols-will be resampled to continue assessment of trends that began during the Regional Aquifer Systems Analysis (RASA) study (Hull, 1984). The water chemistry data from the Sacramento subunit survey will complement the urban land-use study planned for the Sacramento metropolitan area located within this subunit, and also to the rice land-use study, which is partly located within this subunit. The data will provide a comparison of the water chemistry of deeper ground water used for public supply with that of shallower ground water in the land-use areas. If possible, shallow wells, drilled for land-use studies, will be installed near the deeper wells sampled for the subunit surveys.

\section{Tehama South}

The subunit with the second highest ground water use and population in the Sacramento River Basin is the Tehama South subunit, located on the southwestern side of the Sacramento Valley. It consists of alluvial fans deposited by streams draining the Coast Ranges to the west and interfingering with flood basin and channel deposits of the Sacramento River. The study design will follow that of the Sacramento subunit.

\section{VOLATILE ORGANIC COMPOUNDS STUDIES}

\section{Pesticides in Sacramento Air}

Air sampling in the Sacramento area is being done by the Sacramento River Basin NAWQA group as part of an ongoing, cooperative project with the CRWQCB. The CRWQCB has demonstrated with a study completed during the winter of 1994 to 1995 that rainfall throughout the Central Valley can have elevated concentrations of the pesticide diazinon (Valerie Connor, California Regional Water Quality Control Board, written commun., 1995). The measured concentrations were usually above $1 \mu \mathrm{g} / \mathrm{L}$ and many samples had measured diazinon concentrations near $5 \mu \mathrm{g} / \mathrm{L}$. Concentrations above $0.35 \mu \mathrm{g} / \mathrm{L}$ are toxic to aquatic organisms, such as Ceriodaphnia dubia (Amato and others, 1992). The air sampling program is designed to assess the amount of diazinon entering urban runoff by atmospheric transport and by deposition from dormant orchard spray drift during the winter months. The CRWQCB interests are focused on diazinon concentrations in air and rain during the dormant orchard spray season; however, air sampling will continue throughout the year. All air samples and selected rain samples will be analyzed at the Sacramento Mass Spectrometry Laboratory by the Sacramento River Basin NAWQA group for a broad suite of pesticides used in northern and central California. The sites selected for this study are shown in figure 18.

This cooperative study dovetails with NAWQA's Volatile Organic Chemical National Synthesis plans to study organic chemicals in the urban hydrologic cycle. One or two additional air sampling sites will be established in the Arcade Creek drainage area specifically for NAWQA's VOC study. 
EXPLANATION

Sacramento Valley boundary

State water use area

$=$ Study unit boundary

22 Number refers to groundwater use (in acre-feet) in respective state water use areas

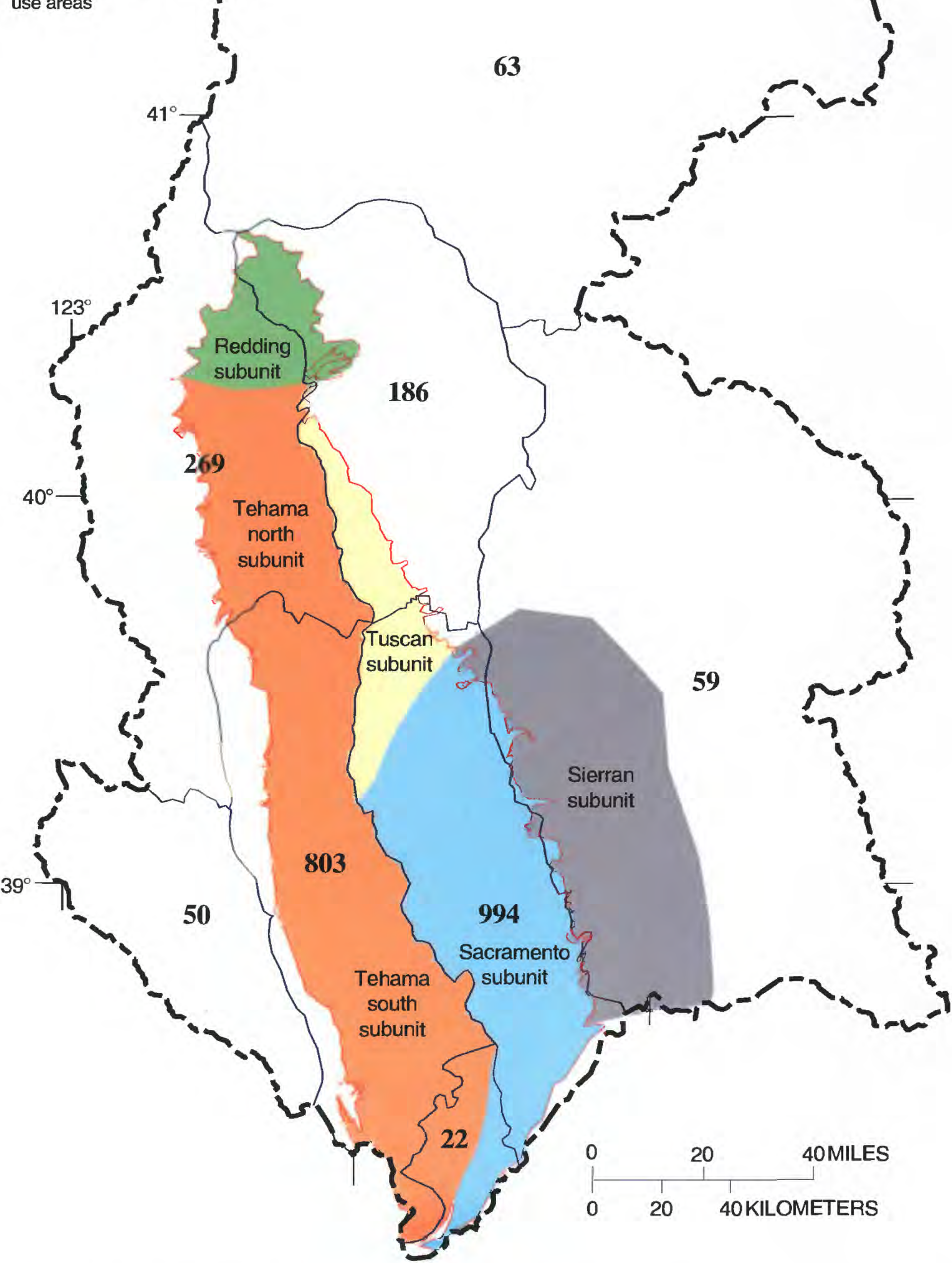

Figure 17. Major aquifer subunits and ground water use for 1989 in the Sacramento River Basin, California. 


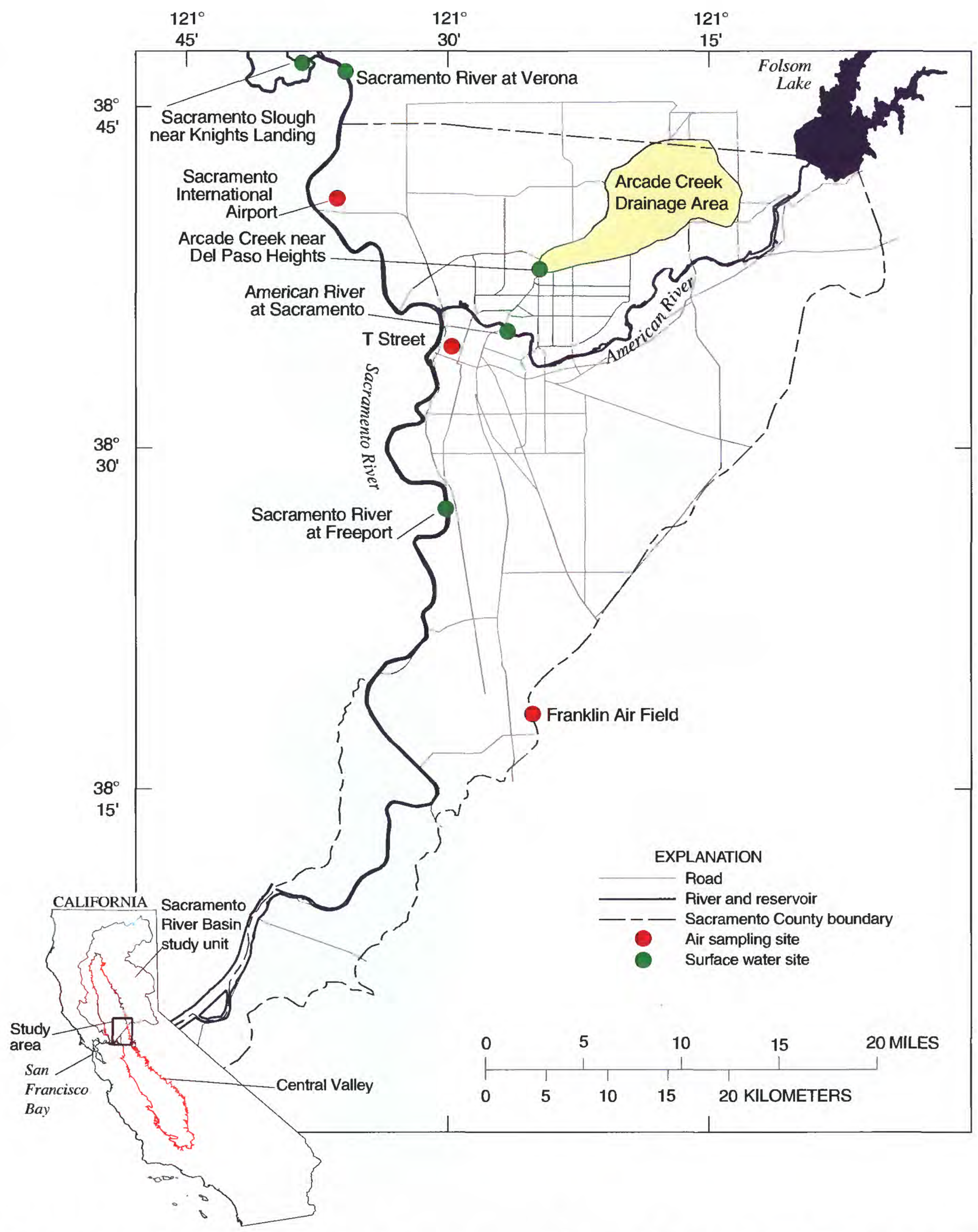

Figure 18. Air and surface water sampling sites for volatile organic compounds, Sacramento River Basin, California, National Water-Quality Assessment Program. 
Several potential sites have been examined, but none have been established at this time. Both air and rain are being collected and analyzed for selected pesticides and VOCs at the Arcade Creek near Del Paso Heights site (site 9). The existing sampling sites in the Sacramento River Basin NAWQA and CRWQCB studies will provide valuable background information on the temporal trends and spatial distribution of airborne diazinon and other selected pesticides entering the urban study area.

The established air sampling sites for the Sacramento River Basin NAWQA and CRWQCB studies are near orchards north of Sacramento, in downtown Sacramento, and in a predominantly pasture area south of Sacramento. These sites follow the Sacramento River and are near several basic fixed and intensive fixed-site surface water sampling locations on the river. Each of the three air sampling sites consists of an air sampling unit and a meteorological station that monitors wind speed and direction, air temperature and relative humidity, and rainfall.

Air samples have been collected throughout the year (1996) using polyurethane foam (PUF) as the collection matrix. Each site consists of two air sampling units. One is operational for 5 min every half-hour when the wind speed is above $1 \mathrm{~m} / \mathrm{s}$ and the wind direction is predominantly from the north (between 315 and 45 degrees). The other sampler is operational for $5 \mathrm{~min}$ every half-hour when the wind speed is above $1 \mathrm{~m} / \mathrm{s}$ and the wind direction is predominantly from the south (between 135 and 225 degrees). Each air sample will be a 7-day, low-volume (approximately 100 liters per minute) composite. Winter storms are predominantly from the north, but wind patterns are from the southwest as storms approach, and this type of directional sampling scheme provides information of when and from which general direction the airborne pesticides are coming from. Bulk rain samples have been collected only during storms throughout the winter season by CRWQCB personnel, except at the Arcade Creek near Del Paso Heights site (site 9).

Air sampling at the Arcade Creek near Del Paso Heights site (site 9) will be slightly different from the existing air sampling procedures and will conform to the NAWQA national air sampling protocols. These samples also will be 7-day composites, but will be high-volume samples (approximately 1,000 L/min) collected for $5 \mathrm{~min}$ every hour. The air will be first pulled through a glass fiber filter (GFF) followed by
PUF. The GFF and PUF will be analyzed separately for pesticides at the USGS National Water Quality Laboratory (NWQL) in Arvada, Colorado. Rain will be collected on a storm basis using automated wet-dry deposition samplers and national sampling protocols. Air and rain samples will be collected and analyzed for VOCs in an as yet-to-be determined method.

An additional study investigating the occurrence and distribution of mercury in the atmosphere also is under consideration. The contribution of atmospheric deposition of mercury to surface water loads in the Sacramento River Basin has not been fully explored, but is considered to be an important pathway. The design of a pilot study currently is being discussed.

\section{Volatile Organic Compounds in Surface Water}

One site has been chosen for sampling of VOCs in surface water-Arcade Creek near Del Paso Heights (site 9; urban indicator site) in Sacramento. This site will be an intensive fixed site for VOCs. The Sacramento River may be sampled for VOCs for special studies. The Sacramento River is particularly suited for the study of VOCs, especially those associated with urban runoff. The physical feature of the Sacramento River that makes it most attractive for study is its depth-close to $30 \mathrm{ft}$-which is uniform for many river miles both upstream and downstream of the urban area. It has no shallow or riffle zones that would result in the accelerated loss of VOCs. Finally, the water depths are such that once VOCs become mixed in the water column, their residence time in the river largely will be a function of individual physical properties, stream temperature, and rate of input. It is expected that many VOCs in the Sacramento River will have a long residence time and will be transported a considerable distance downstream. Therefore, appropriate studies can address that transport.

\section{ACID-MINE DRAINAGE}

Elevated concentrations of copper, lead, and zinc in the upper Sacramento River have resulted in water quality degradation because of acid-mine drainage runoff from Spring Creek (fig. 1). Although the site has undergone some mitigation, questions about the effectiveness of the mitigation effort remain, especially the fate of the several-meter-thick sections 
of chemically precipitated sediments in Keswick Reservoir. Resuspension of those sediments can transport copper and other metals in sufficiently high concentrations to cause fish mortality in the Sacramento River. Elevated concentrations of the metals also can persist throughout the entire length of the river. The transport of those metals in solution, and in association with colloidal particles and suspended sediment, will be addressed through a cooperative study with the Sacramento County Regional Sanitation District. Metals_-including cadmium, copper, lead, mercury, and zinc - will be analyzed in those samples.

The elevated levels of copper in the Sacramento River may be attributable principally to the abandoned mines, but also may be a result of runoff from agricultural fields. About one million pounds of copper sulfate are added to rice fields each year for algae control. The sampling of dissolved metals at the basic and intensive fixed sites, along with this special study, may allow for the differentiation among the possible sources, agricultural or mining.

\section{SUMMARY}

The environmental setting and study plan for the Sacramento River Basin National Water-Quality Assessment Program is presented in this report. Investigative activities for surface water studies, biological investigations, and ground water programs are described. These data collection activities will take place between 1995 and 1998. A network of surface water sites was selected for water quality sampling. Sites were selected on the main stem of the Sacramento River and at downstream locations of major tributaries. In addition, two agricultural, one agricultural plus mining, and one urban site were selected to assess the effects of those land uses on the water quality of the Sacramento River. Biological assessments are planned for the occurrence of trace elements and hydrophobic organic contaminants in stream sediment and animal tissue, for habitat and aquatic community surveys at various sites, and for habitat and aquatic community surveys of multiple stream reaches at four sites. Ground water studies will include a subunit survey of at least the eastern
Sacramento Valley and possibly the western

Sacramento valley (Tehama South subunit) and two land use surveys-agriculture (rice) and urban (Sacramento metropolitan area).

A special study on trace elements is planned to investigate the transport and geochemistry of a suite of metals including copper, cadmium, zinc, and mercury from an acid mine drainage site located in the upper Sacramento River Basin. Special studies on the air transport of pesticides are also planned.

The variability of volatile organic compound concentrations during stormwater runoff will be investigated for Arcade Creek. In addition, the transport of volatile organic compounds in the Sacramento River may also be investigated.

\section{REFERENCES CITED}

Amato, J.R., Mount, D.I., Durhan, E.J., Lukasewycz, M.T., Ankley, G.T., and Robert, E.D., 1992, An example of the identification of diazinon as a primary toxicant in an effluent: Environmental Toxicology and Chemistry, v. 11 , no. 2, p. 209-216.

California Department of Water Resources, 1993, California Water Plan Update: California Department of Water Resources, Bulletin 160-93, v. 2, 347 p.

California State Water Resources Control Board, 1990, Toxic Substances Monitoring Program-Ten Year Summary Report 1978-1987: State of California, Water Resources Control Board, 133 p., 15 appendixes.

Clark, B.L., and Anderson, C.A., 1938, Upper Eocene Wheatland Formation of California and its relation to early Tertiary andesites in the Sierra Nevada: Geological Society of America Bulletin, v. 49, p. 931-956.

Domagalski, J., 1996, Pesticides and pesticide degradation products in stormwater runoff: Sacramento River Basin, California: Journal of the American Water Resources Association, v. 32, p. 953-964.

Gilliom, R.J., Alley, W.M., and Gurtz, M.E., 1995, Design of the National Water-Quality Assessment Program: Occurrence and distribution of water-quality conditions: U.S. Geological Survey Circular 1112, $33 \mathrm{p}$.

Hull, L.C., 1984, Geochemistry of ground water in the Sacramento Valley, California: U.S. Geological Survey Professional Paper 1401-B, 36 p. 
Jacobs, D., Chatfield, E., Kiley, L., Mathias-Kondolf, G., Lloyd, L., Smith, F., Walker, D., and Walker, K., 1993, California rivers-A public trust report: California State Lands Commission, 334 p.

Kuivila, K.M. and Foe, C.G., 1995, Concentrations, transport and biological effects of dormant spray pesticides in the San Francisco Estuary, California: Environmental Toxicology and Chemistry, v. 14, no. 7, p. 1141-1150.

Norris, R.M., and Webb, R.W., 1990, Geology of California (2nd ed.): New York, John Wiley and Sons, Incorporated, $541 \mathrm{p}$.

Omernik, J.M., 1986, Ecoregions of the conterminous United States: Corvallis Environmental Research Laboratory, U.S. Environmental Protection Agency, Supplement to the Annals of the Association of American Geographers, v. 77, no. 1, p. 118-125.

Page, R.W., 1986, Geology of the fresh ground-water basin of the Central Valley, California, with texture maps and sections, Regional Aquifer-System Analysis: U.S.
Geological Survey Professional Paper 1401-C, 54 p., 5 plates in pocket.

San Francisco Bay Regional Water Quality Control Board, 1995, Contaminant levels in fish tissue from San Francisco Bay: San Francisco Bay Regional Water Quality Control Board Final Report, June, 1995, 135 p.

Schoenherr, A.A., 1992, A natural history of California: Berkeley, University of California Press, California Natural History Guides Series no. 56, 772 p.

Soil Conservation Service, 1993, State soil geographic base (STATSGO)_Data use: U.S. Department of Agriculture, Miscellaneous Publication 1492, 88 p.

U.S. Department of Commerce, 1992, 1990 Census of population and housing: Summary social, economic, and housing characteristics: U.S. Department of Commerce, Economics and Statistics Administration, Bureau of the Census, variously paged.

Zilloux, E.J., Porcella, D.B., and Benoit, J.M., 1993, Mercury cycling and effects in freshwater wetland ecosystems: Environmental Toxicology and Chemistry, v. 12 , p. $2245-2264$. 